Article

\title{
Recyclable Aggregates of Mesoporous Titania Synthesized by Thermal Treatment of Amorphous or Peptized Precursors
}

\author{
Maria Cristina Mascolo ${ }^{1, *}$ (D) and Terry Arthur Ring ${ }^{2}$ \\ 1 Laboratory of Materials, Department of Civil and Mechanical Engineering, \\ University of Cassino and Southern Latium, G. Di Biasio 43 Street, 03043 Cassino (FR), Italy \\ 2 Department of Chemical Engineering, University of Utah, Salt Lake City, UT 84112, USA; ring@eng.utah.edu \\ * Correspondence: mc.mascolo@unicas.it; Tel.: +39-0776-2994346; Fax: +39-0776-2993711
}

Received: 8 December 2017; Accepted: 1 March 2018; Published: 5 March 2018

\begin{abstract}
Recyclable aggregates of mesoporous titania with different anatase-rutile ratios have been prepared by thermal treatments of either amorphous or peptized precursors. These last two have been obtained by hydrolysis of either $\mathrm{Ti}\left(\mathrm{OC}_{2} \mathrm{H}_{5}\right)_{4}$ or of $\mathrm{Ti}\left(\mathrm{OC}_{2} \mathrm{H}_{5}\right)_{4}$ in mixture with $5 \mathrm{~mol} \%$ $\mathrm{Zr}\left(\mathrm{OC}_{3} \mathrm{H}_{7}\right)_{4}$ at room temperature in the presence of $\mathrm{NH}_{4} \mathrm{OH}$ as a catalyzing agent. The anatase-rutile ratio, the recyclable aggregates of the nano-sized particles, the mesoporosity, the surface area and the crystallinity of the resulting crystallized products of titania can be controlled by the synthesis parameters including: concentration of ammonia catalyst, stirring time and concentration of the peptizing $\mathrm{HNO}_{3}$, drying method of peptized precursors, calcination temperature, and finally the ramp rate up to the titania crystallization temperature. A broad range of synthesis parameters control the crystal sizes of titania particles produced. This allows catalyst preparation with very different crystal size, surface area, anatase to rutile crystal ratio and various mesoporous structures. Drying by lyophilization of precursors reduce the aggregation of the primary particles giving micro-/macroporous structures.
\end{abstract}

Keywords: amorphous and peptized precursors; peptizing $\mathrm{HNO}_{3}$; thermal crystallization; drying effect; micrometer aggregates; mesoporous titania

\section{Introduction}

Titania $\left(\mathrm{TiO}_{2}\right)$ has attracted noticeable attention for numerous applications in various research areas including pigments, photo-catalysis, dye-sensitized solar cells, lithium ion batteries, sensor devices, protective coatings, sunscreen cosmetics and solar water splitting [1-9]. The effectiveness of $\mathrm{TiO}_{2}$ in practical applications relies upon its physical-chemical properties that depend on the synthesis of nano-sized titania particles. The efficiency of titania strongly depends on its structure in terms of crystallinity, morphology, crystallite size, porosity, surface area, doping and the presence of one or more polymorph phases [10-15].

The application of $\mathrm{TiO}_{2}$ powders in heterogeneous photo-catalysis reveals some drawbacks: the trouble to separate the powder from the aqueous dispersion making the recycling difficult and the tendency of the nano-particles to agglomerate leading to a reduction of the photo-catalytic reaction surface area [16]. On the other hand the immobilization of titania as a thin film reduces agglomeration but decreases the catalyst surface area [17-19]. In previous investigations mesoporous anatase samples, in the form of recyclable aggregates, have been prepared by hydrothermal treatments [20-22].

This work describes the synthesis of mesoporous titania aggregates by thermal treatments of either amorphous or crystalline precursors prepared at room temperature either by hydrolysis of either $\mathrm{Ti}\left(\mathrm{OC}_{2} \mathrm{H}_{5}\right)_{4}$ or $\mathrm{Ti}\left(\mathrm{OC}_{2} \mathrm{H}_{5}\right)_{4}$ in mixture with $\mathrm{Zr}\left(\mathrm{OC}_{3} \mathrm{H}_{7}\right)_{4}(5 \mathrm{~mol} \%)$ and both catalysed with ammonia. 
The resulting xerogels and those peptized with $\mathrm{HNO}_{3}$ were submitted to thermal treatment that resulted in crystallization/coarsening. The experimental objective is to obtain recyclable aggregates of mesoporous titania with high values of both crystallinity and surface area, either as anatase form or as binary mixtures of the three different crystalline polymorphs of titania: anatase, rutile and brookite, respectively. It is well known that the co-presence of various crystallographic forms of $\mathrm{TiO}_{2}$ favours its photo-activity [23]. The Degussa commercial product P25 consists of a mixture of anatase and rutile, for example.

\section{Experimental}

The hydrolysis of $\mathrm{Ti}\left(\mathrm{OC}_{2} \mathrm{H}_{5}\right)_{4}$ (R.G., Sigma-Aldrich, Saint Louis, MO, USA) and mixtures of $\mathrm{Ti}\left(\mathrm{OC}_{2} \mathrm{H}_{5}\right)_{4}$ with $\mathrm{Zr}\left(\mathrm{OC}_{3} \mathrm{H}_{7}\right)_{4}(5 \mathrm{~mol} \%)$ was performed at room temperature in ethanol obtaining the amorphous precursors of titania. According to the previous procedures [20], the hydrolysis treatments were carried out under continuous stirring and in the presence of different concentrations of $\mathrm{NH}_{4} \mathrm{OH}$ as catalysing agent, with reaction time of $1 \mathrm{~h}$. The precipitates $(0.05 \mathrm{~mol})$ were washed three times with de-ionized water and separated by centrifugation. Some of these products were dried in an oven at $60{ }^{\circ} \mathrm{C}$ obtaining the corresponding xerogels. Other products were directly peptized under continuous stirring at $50^{\circ} \mathrm{C}$ in the presence of $50 \mathrm{~mL}$ of aqueous solution of $\mathrm{HNO}_{3} 0.02 \mathrm{M}$ or $0.1 \mathrm{M}$, using treatment times of $1 \mathrm{~h}$ or $3 \mathrm{~h}$, respectively. It should be noted that adopting a peptizing temperature higher than $50{ }^{\circ} \mathrm{C}$ or a treatment time with $0.1 \mathrm{M} \mathrm{HNO}_{3}$ for longer than $3 \mathrm{~h}$, or the presence of a more concentrated $\mathrm{HNO}_{3}$ solution results in the complete dissolution of the xerogel.

The peptized products, without washing with deionized water, were dried by lyophilization, using a Lio Cinquepascal apparatus (Milan, Italy), or at room temperature in the presence of silica gel or in an oven at $60^{\circ} \mathrm{C}$. Both peptized and un-peptized samples were thermally treated from $250{ }^{\circ} \mathrm{C}$ up to $600{ }^{\circ} \mathrm{C}$ for $2 \mathrm{~h}$ adopting a ramp rate of 2 or $30^{\circ} \mathrm{C} / \mathrm{min}$, respectively.

Reaction products were characterized by X-ray diffraction (XRD) analysis using a Philips diffractometer and $\mathrm{Cu} \mathrm{K} \alpha$ radiation. The mass fraction of anatase and rutile was determined using Equations (1) and (2) [24,25]:

$$
\begin{aligned}
& \text { Anatase }(\%)=\left[0.79 \mathrm{I}_{\mathrm{A}} /\left(0.79 \mathrm{I}_{\mathrm{A}}+\mathrm{I}_{\mathrm{R}}\right)\right] \times 100 \\
& \text { Rutile }(\%)=\left\{1 /\left[\left(0.79 \mathrm{I}_{\mathrm{A}}+\mathrm{I}_{\mathrm{R}}\right) / \mathrm{I}_{\mathrm{R}}\right]\right\} \times 100,
\end{aligned}
$$

where $I_{A}$ and $I_{R}$ are the peak intensities of [101] and [110] reflections for anatase and rutile, respectively. Differential thermal analysis (DTA) and thermo-gravimetric analysis (TGA) were performed in air with a heating rate of $10{ }^{\circ} \mathrm{C} / \mathrm{min}$ using a Netzsch model 409 thermoanalyzer (Selb, Germany) and $\alpha$-alumina as reference material. The chemical structure of the prepared particles was examined by using a Fourier transform infrared spectrophotometer (FTIR, Bruker, IFS-88, Billerica, MA, USA) in the range from 4000 to $600 \mathrm{~cm}^{-1}$ with a $2 \mathrm{~cm}^{-1}$ resolution.

The specific surface area was measured by the BET method utilizing $\mathrm{N}_{2}$ as adsorbed after drying at $80{ }^{\circ} \mathrm{C}$ for $12 \mathrm{~h}$. The average pore diameter was estimated by the desorption branch of the isotherm and the $\mathrm{BJH}$ formula, while the total pore volume was obtained from the volume of $\mathrm{N}_{2}$ adsorbed at $\mathrm{P} / \mathrm{P}_{0}=0.995$. The morphologies of synthesized products were examined, after gold coating, by scanning electron microscopy (SEM), using a Philips microscopy (XL series, Almelo, The Netherlands) equipped by energy-dispersive X-ray spectroscopy (EDX) for the elemental analysis.

\section{Results}

\subsection{Thermal Behaviour of the Xerogels}

The xerogels obtained by hydrolysis at room temperature of both $\mathrm{Ti}\left(\mathrm{OC}_{2} \mathrm{H}_{5}\right)_{4}$ and mixtures of $\mathrm{Ti}\left(\mathrm{OC}_{2} \mathrm{H}_{5}\right)_{4}$ with $\mathrm{Zr}\left(\mathrm{OC}_{3} \mathrm{H}_{7}\right)_{4}\left(5 \mathrm{~mol} \%\right.$ ) both catalysed with different concentrations of $\mathrm{NH}_{4} \mathrm{OH}$ resulted in XRD amorphous xerogels. Both pure titania and titania containing $5 \mathrm{~mol} \%$ of zirconia 
xerogels show a broad endothermic DTA peak with maximum around $160{ }^{\circ} \mathrm{C}$ due to water loss (Figure 1a,b). The exothermic peak at $361^{\circ} \mathrm{C}$ for the pure titania xerogel is due to the crystallization of anatase (Figure 1a), while such transformation for the xerogel with $5 \mathrm{~mol} \%$ of zirconia takes place at higher temperature with a strong and sharp peak at $472{ }^{\circ} \mathrm{C}$ (Figure 1b). Pure titania xerogel shows a very broad exothermic peak between $600{ }^{\circ} \mathrm{C}$ and $900{ }^{\circ} \mathrm{C}$ with a maximum at $800{ }^{\circ} \mathrm{C}$ attributable to the anatase-rutile transformation. This peak is absent for the xerogel containing $5 \mathrm{~mol} \%$ of zirconia confirming that zirconia inhibits the transformation of anatase into rutile [26].

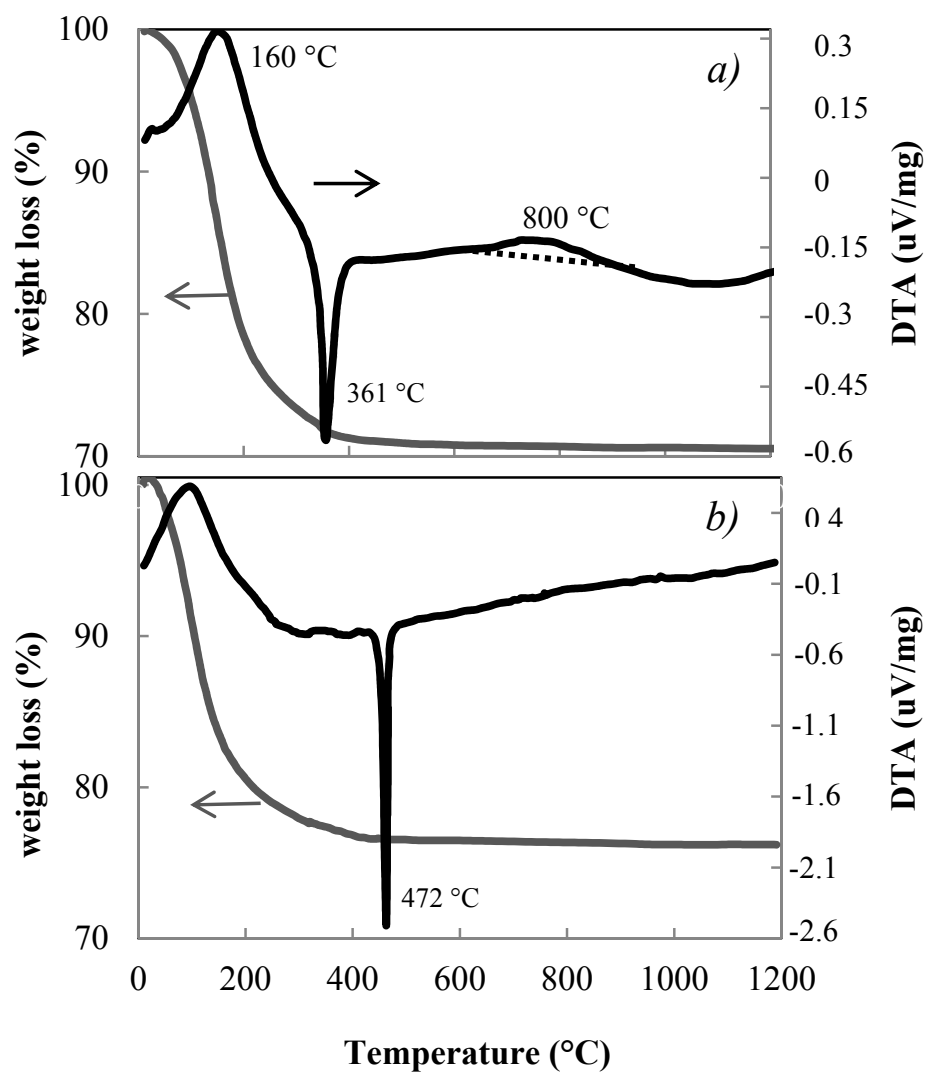

Figure 1. DTA and TGA of xerogels of pure titania (a) and of titania containing $5 \mathrm{~mol} \%$ of zirconia (b).

\subsection{Peptization of $\mathrm{TiO}_{2}$ Xerogels with $\mathrm{HNO}_{3}$}

\subsubsection{Effect of the Concentration}

The peptizing treatment at $50{ }^{\circ} \mathrm{C}$ of $\mathrm{TiO}_{2}$ xerogel at $\mathrm{pH}=1$ in the presence of $0.1 \mathrm{M} \mathrm{HNO}_{3}$ favours the crystallization of anatase with traces of brookite, while at $\mathrm{pH}=6.5$ with $0.02 \mathrm{M} \mathrm{HNO}_{3}$ little crystallization of anatase results. The XRD patterns of Figure 2, show the xerogels catalysed for $1 \mathrm{~h}$ with $0.07 \mathrm{M} \mathrm{NH}_{4} \mathrm{OH}$ (Figure $2 \mathrm{a}-\mathrm{c}$ ) or $1.0 \mathrm{M} \mathrm{NH}_{4} \mathrm{OH}$ (Figure 2d-f), and comparisons with un-peptized (Figure 2a,d) and peptized samples for $1 \mathrm{~h}$ in the presence of $0.02 \mathrm{M} \mathrm{HNO}_{3}$ (Figure $2 \mathrm{~b}, \mathrm{c}$ ) or $0.1 \mathrm{M} \mathrm{HNO}_{3}$ (Figure 2e,f). An amorphous product results without the peptizing treatment (Figure 2a,d), while increasing crystallinity of anatase results for samples peptized with increasing concentrations of $\mathrm{HNO}_{3}$ (Figure 2b,c,e,f). When the peptizing treatment time was either longer than $5 \mathrm{~h}$ or in the presence of $\mathrm{HNO}_{3}$ with a concentration higher than $0.1 \mathrm{M}$, the dissolution of the products resulted. 


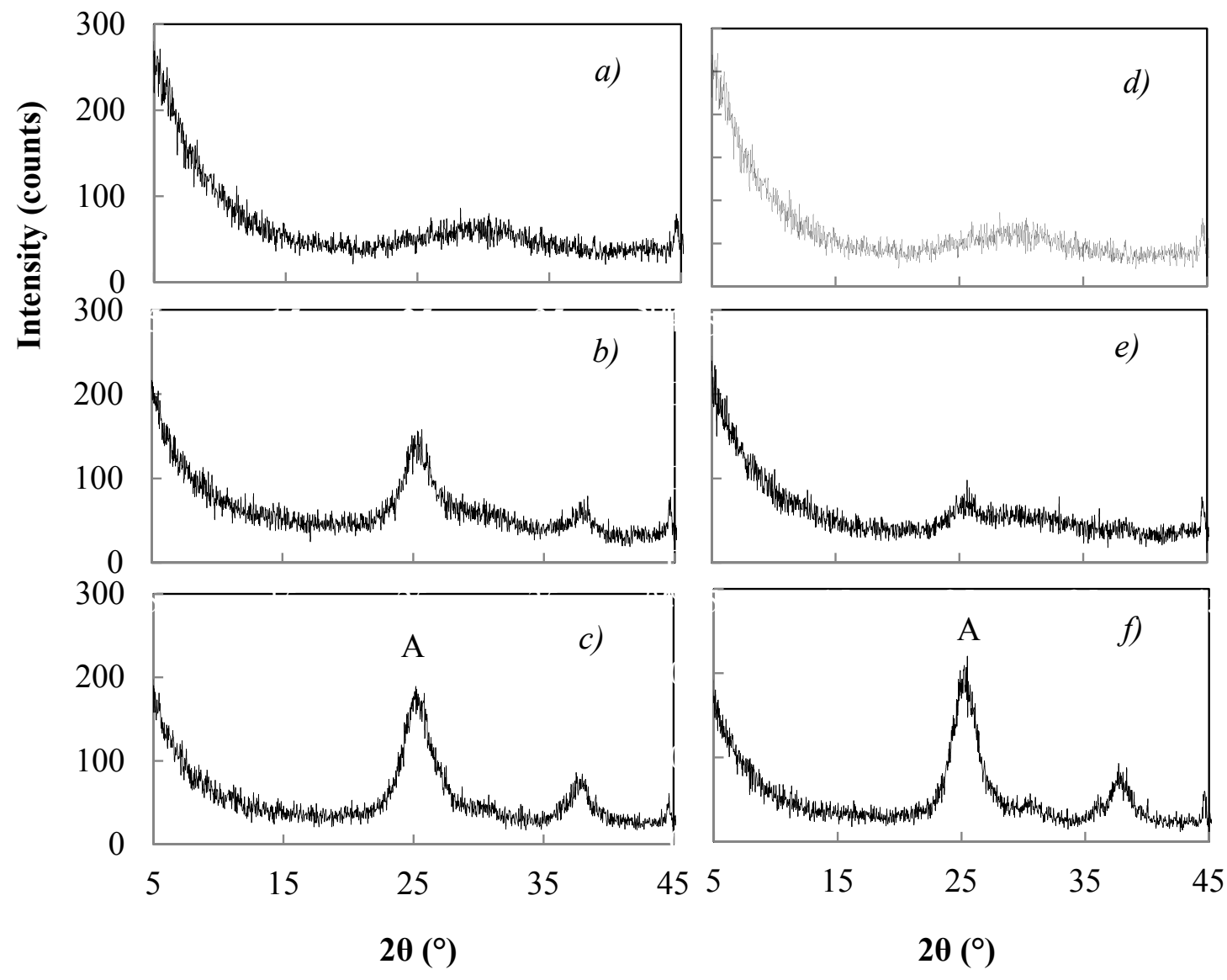

Figure 2. XRD patterns of products hydrolyzed for $1 \mathrm{~h}$ in the presence of $\mathrm{NH}_{4} \mathrm{OH} 0.07 \mathrm{M}(\mathbf{a}-\mathbf{c})$ or $1.0 \mathrm{M}$ $(\mathbf{d}-\mathbf{f})$ and subsequently treated for $1 \mathrm{~h}$ with $\mathrm{HNO}_{3} 0.02 \mathrm{M}(\mathbf{b}, \mathbf{e})$ or $0.1 \mathrm{M}(\mathbf{c}, \mathbf{f})$. (A = anatase).

The presence of nitrogen in the peptized samples has been detected by IR spectra (Figure 3) in which the asymmetric stretching band of $\mathrm{NO}_{3}{ }^{-}$ion at $1383 \mathrm{~cm}^{-1}$ appears together the broad absorption peak at $3102 \mathrm{~cm}^{-1}$ related to a stretching vibration of the $\mathrm{O}-\mathrm{H}$ group and a peak at $1627 \mathrm{~cm}^{-1}$ assigned to water.

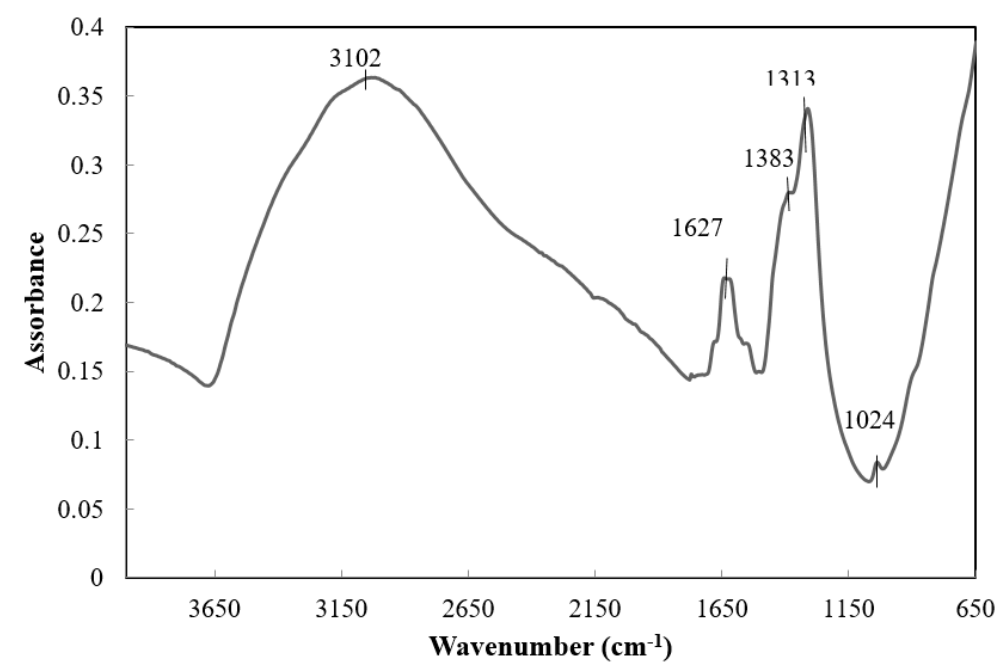

Figure 3. FT-IR spectra of product hydrolyzed for $1 \mathrm{~h}$ in the presence of $\mathrm{NH}_{4} \mathrm{OH} 1.0 \mathrm{M}$ and subsequently treated for $1 \mathrm{~h}$ with $0.1 \mathrm{M} \mathrm{HNO}_{3}$. 


\subsubsection{Effect of Treatment Time of Peptization}

The treatment times of peptization of titania gel under stirring were 1 or $3 \mathrm{~h}$, respectively. The crystallinity of the resulting anatase with traces of brookite was practically unaffected by both the concentration of the hydrolyzing $\mathrm{NH}_{4} \mathrm{OH}$ and by the treatment time of the gel when a constant concentration of $\mathrm{HNO}_{3}$ was used.

The crystal sizes of these samples were determined from the line broadening of [101] peak of anatase using the Sherrer formula. The resulting average crystal sizes and the corresponding polymorphic form of titania are reported in Table 1. Crystal sizes do not vary much, only about $4.7 \mathrm{~nm}$, and a trace of brookite was found in all samples.

In order to obtain the formation of mesoporous titania, a thermal treatment of both un-peptized and peptized products must be performed. It assures both the complete crystallization of titania and a certain amount of coarsening of the very small crystals of anatase resulting from the peptizing treatment.

Table 1. Crystal sizes and polymorphic forms of titania for the samples reported in Figure 3.

\begin{tabular}{ccccc}
\hline Sample & $\begin{array}{c}\mathbf{N H}_{4} \mathrm{OH} \text { Concentration/ } \\
\text { Treatment Time (M/h) }\end{array}$ & $\begin{array}{c}\mathbf{H N O}_{3} \text { Concentration/ } \\
\text { Treatment Time (M/h) }\end{array}$ & $\begin{array}{c}\text { Crystal Size (nm) } \\
\text { by XRD }\end{array}$ & $\begin{array}{c}\text { Polymorphic Phases A } \\
\text { (Anatase), B (Brookite) }\end{array}$ \\
\hline A & $0.07 / 1$ & $0.1 / 1$ & 4.8 & A, B (traces) \\
B & $0.07 / 1$ & $0.1 / 3$ & 4.7 & A, B (traces) \\
C & $1.0 / 1$ & $0.1 / 1$ & 4.7 & A, B (traces) \\
D & $1.0 / 1$ & $0.1 / 3$ & 4.6 & A, B (traces) \\
\hline
\end{tabular}

\subsection{Thermal Treatments of Peptized Titania}

After calcination at $450{ }^{\circ} \mathrm{C}$ the peptized samples show IR spectra characterized by a significant decrease in both the $\mathrm{OH}$ group and water band intensities. The band of $\mathrm{NO}_{3}{ }^{-}$ion at $1383 \mathrm{~cm}^{-1}$ also significantly decreases after calcination.

Table 2 summarizes the characteristics of the products resulting from the hydrolysis of $\mathrm{Ti}\left(\mathrm{OC}_{2} \mathrm{H}_{5}\right)_{4}$ for $1 \mathrm{~h}$ in the presence either 0.07 or $0.1 \mathrm{M} \mathrm{NH}_{4} \mathrm{OH}$ that is subsequently peptized for 1 or $3 \mathrm{~h}$ with $0.02 \mathrm{M}$ or $0.1 \mathrm{M} \mathrm{HNO}_{3}$, and finally heat treated for $2 \mathrm{~h}$ at different temperatures up to $600{ }^{\circ} \mathrm{C}$ using ramp rates of $2^{\circ} \mathrm{C}$ or $30^{\circ} \mathrm{C} \cdot \mathrm{min}^{-1}$, respectively.

Table 2. BET surface area, average pore diameter, crystal size and percentage of polymorphic phases of titania for products hydrolyzed for $1 \mathrm{~h}$ with $\mathrm{NH}_{4} \mathrm{OH} 0.07 \mathrm{M}$ or $0.1 \mathrm{M}$, subsequently treated or not for $1 \mathrm{~h}$ or $3 \mathrm{~h}$ with $\mathrm{HNO}_{3} 0.02 \mathrm{M}$ or $0.1 \mathrm{M}$, and finally heat treated for $2 \mathrm{~h}$ at different temperatures up to $600{ }^{\circ} \mathrm{C}$ using heating rates of 2 or $30^{\circ} \mathrm{C} \cdot \mathrm{min}^{-1}$, respectively.

\begin{tabular}{|c|c|c|c|c|c|c|c|}
\hline Sample & $\begin{array}{c}\mathrm{NH}_{4} \mathrm{OH} \\
\text { Concentration/ } \\
\text { Treatment Time } \\
(\mathrm{M} / \mathrm{h})\end{array}$ & $\begin{array}{c}\mathrm{HNO}_{3} \\
\text { Concentration/ } \\
\text { Treatment Time } \\
(\mathrm{M} / \mathrm{h})\end{array}$ & 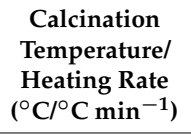 & $\begin{array}{c}\text { BET } \\
\text { Surface } \\
\text { Area } \\
\left(\mathrm{m}^{2} / \mathrm{g}\right)\end{array}$ & $\begin{array}{l}\text { Average } \\
\text { Pore } \\
\text { Diameter } \\
(\mathrm{nm})\end{array}$ & $\begin{array}{l}\text { Crystal } \\
\text { Size by } \\
\text { XRD (nm) }\end{array}$ & $\begin{array}{c}\text { Polymorphic } \\
\text { Phases (\%) A } \\
\text { (anatase) R } \\
\text { (rutile) }\end{array}$ \\
\hline $\mathrm{T} 1$ & $0.07 / 1$ & $0.02 / 1$ & $450 / 2$ & 39.4 & 6.6 & 21.9 & $100 \%(\mathrm{~A})$ \\
\hline $\mathrm{T} 2$ & $0.07 / 1$ & $0.1 / 1$ & $250 / 2$ & - & - & 5.6 & $100 \%(\mathrm{~A})$ \\
\hline $\mathrm{T} 3$ & $0.07 / 1$ & $0.1 / 1$ & $300 / 2$ & - & - & $\begin{array}{c}6.6 \\
13.0\end{array}$ & $\begin{array}{l}74.8(\mathrm{~A}) \\
25.2(\mathrm{R})\end{array}$ \\
\hline $\mathrm{T} 4$ & $0.07 / 1$ & $0.1 / 1$ & $350 / 2$ & - & - & $\begin{array}{c}8.5 \\
14.4 \\
\end{array}$ & $\begin{array}{l}67.5(\mathrm{~A}) \\
32.5(\mathrm{R})\end{array}$ \\
\hline $\mathrm{T} 5$ & $0.07 / 1$ & $0.1 / 1$ & $400 / 2$ & - & - & $\begin{array}{c}9.5 \\
24.1\end{array}$ & $\begin{array}{l}64.8(\mathrm{~A}) \\
35.2(\mathrm{R})\end{array}$ \\
\hline T6 & $0.07 / 1$ & $0.1 / 1$ & $450 / 2$ & - & - & $\begin{array}{l}11.3 \\
24.5\end{array}$ & $\begin{array}{l}30.1(\mathrm{~A}) \\
69.9(\mathrm{R})\end{array}$ \\
\hline $\mathrm{T} 6^{*}$ & $0.07 / 1$ & $0.1 / 1$ & $450 / 2$ & - & - & $\begin{array}{l}15.1 \\
26.4 \\
\end{array}$ & $\begin{array}{c}\mathrm{A}(9.0) \\
\mathrm{R}(91.0)\end{array}$ \\
\hline $\mathrm{T} 7$ & $1.0 / 1$ & $0.02 / 1$ & $450 / 2$ & 70.5 & 3.4 & 13.8 & $100(\mathrm{~A})$ \\
\hline
\end{tabular}


Table 2. Cont.

\begin{tabular}{|c|c|c|c|c|c|c|c|}
\hline Sample & $\begin{array}{c}\mathrm{NH}_{4} \mathrm{OH} \\
\text { Concentration/ } \\
\text { Treatment Time } \\
(\mathrm{M} / \mathrm{h})\end{array}$ & $\begin{array}{c}\mathrm{HNO}_{3} \\
\text { Concentration/ } \\
\text { Treatment Time } \\
(\mathrm{M} / \mathrm{h})\end{array}$ & 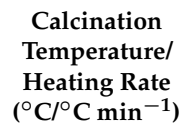 & $\begin{array}{c}\text { BET } \\
\text { Surface } \\
\text { Area } \\
\left(\mathrm{m}^{2} / \mathrm{g}\right)\end{array}$ & $\begin{array}{l}\text { Average } \\
\text { Pore } \\
\text { Diameter } \\
(\mathrm{nm})\end{array}$ & $\begin{array}{l}\text { Crystal } \\
\text { Size by } \\
\text { XRD (nm) }\end{array}$ & $\begin{array}{c}\text { Polymorphic } \\
\text { Phases (\%) A } \\
\text { (anatase) R } \\
\text { (rutile) }\end{array}$ \\
\hline T8 & $1.0 / 1$ & $0.02 / 1$ & $450 / 30$ & 65.5 & 4.0 & 19.8 & $100(\mathrm{~A})$ \\
\hline T9 & $1.0 / 1$ & $0.02 / 3$ & $450 / 2$ & 62.7 & 5.2 & 20.4 & $100(\mathrm{~A})$ \\
\hline $\mathrm{T} 10$ & $1.0 / 1$ & $0.02 / 3$ & $450 / 30$ & - & - & 26.3 & $100(\mathrm{~A})$ \\
\hline T11 & $1.0 / 1$ & $0.1 / 1$ & $450 / 2$ & 46.8 & 3.3 & $\begin{array}{l}12.2 \\
24.1\end{array}$ & $\begin{array}{l}64.9 \text { (A) } \\
35.1(\mathrm{R})\end{array}$ \\
\hline $\mathrm{T} 12$ & $1.0 / 1$ & $0.1 / 1$ & $600 / 2$ & 10.5 & 5.2 & 48.1 & $100(\mathrm{R})$ \\
\hline $\mathrm{T} 13$ & $1.0 / 1$ & $0.1 / 1$ & $450 / 30$ & 70.4 & 5.1 & $\begin{array}{l}20.4 \\
37.2\end{array}$ & $\begin{array}{l}22.8(\mathrm{~A}) \\
77.2(\mathrm{R})\end{array}$ \\
\hline T14 & $1.0 / 1$ & $0.1 / 3$ & $450 / 2$ & 30.3 & 3.3 & $\begin{array}{l}17.0 \\
43.1\end{array}$ & $\begin{array}{l}73.3(\mathrm{~A}) \\
26.7(\mathrm{R})\end{array}$ \\
\hline T15 & $1.0 / 1$ & $0.1 / 3$ & $450 / 30$ & - & - & $\begin{array}{l}25.5 \\
45.5\end{array}$ & $\begin{array}{l}43.7 \text { (A) } \\
56.3(\mathrm{R})\end{array}$ \\
\hline
\end{tabular}

\subsubsection{Sample Hydrolysed with $0.07 \mathrm{M} \mathrm{NH}_{4} \mathrm{OH}$ and Peptized with $0.02 \mathrm{M} \mathrm{HNO}_{3}$}

When the hydrolysis is catalysed in the presence of $0.07 \mathrm{M} \mathrm{NH}_{4} \mathrm{OH}$ and peptized with $0.02 \mathrm{M} \mathrm{HNO}_{3}$, respectively, only anatase crystallizes after calcination at $450{ }^{\circ} \mathrm{C}$ for $2 \mathrm{~h}$ (sample T1). This sample has a mesoporous structure according to the hysteresis of the $\mathrm{N}_{2}$ absorption-desorption curves shown in Figure 4 . This sample is characterized by a surface area of $39.4 \mathrm{~m}^{2} / \mathrm{g}$, crystal size of $21.9 \mathrm{~nm}$ and an average pore diameter of $6.6 \mathrm{~nm}$ measured using the desorption branch of $\mathrm{N}_{2}$ by the isotherm using BJH formula.

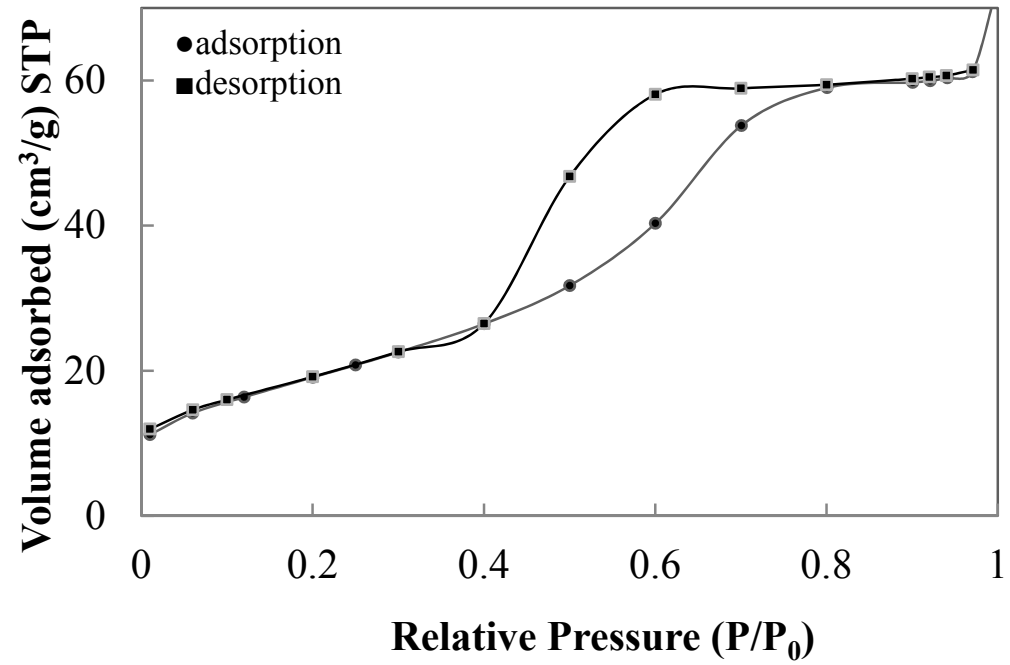

Figure $4 . \mathrm{N}_{2}$ absorption-desorption curves of the sample T1 reported in Table 2.

\subsubsection{Samples Hydrolysed with $0.07 \mathrm{M} \mathrm{NH}_{4} \mathrm{OH}$ and Peptized with $0.1 \mathrm{M} \mathrm{HNO}_{3}$}

The precursor of these samples, corresponding to the A sample listed in Table 1, contains anatase with very small crystal size and traces of brookite. The DTA and TGA (Figure 5) of this sample shows a broad exothermal peak at very low temperatures, in the range between $300{ }^{\circ} \mathrm{C}$ and $600{ }^{\circ} \mathrm{C}$ with a maximum at $500^{\circ} \mathrm{C}$, which is due to the anatase-rutile transformation. The large endo-thermal peak with maximum at $151{ }^{\circ} \mathrm{C}$ can be attributed to the water loss prevalently related to both adsorbed water and hydroxyls decomposition. The weight loss at higher temperature can be related either to further de-hydroxylation and/or to nitrate evolution adsorbed during the peptizing treatment. 
The samples T2, T3, T4, T5 and T6 (Table 2) differ only in the calcination temperature of precursor A (Table 1). Calcination temperatures varied between $250^{\circ} \mathrm{C}$ and $450{ }^{\circ} \mathrm{C}$. The sample was firstly treated for $2 \mathrm{~h}$ at $250{ }^{\circ} \mathrm{C}$ and cooled at room temperature (Sample T2), then it was re-treated for $2 \mathrm{~h}$ at $300{ }^{\circ} \mathrm{C}$ and cooled (Sample T3). Analogous heat treatments were performed at $350{ }^{\circ} \mathrm{C}$ (Sample T4), $400{ }^{\circ} \mathrm{C}$ (Sample T5) and $450^{\circ} \mathrm{C}$ (Sample T6), respectively. It can be seen from the XRD patterns of Figure 6 that at $250{ }^{\circ} \mathrm{C}$ crystalline anatase is the main phase with traces of rutile and brookite. At $300{ }^{\circ} \mathrm{C}, 350{ }^{\circ} \mathrm{C}$ and $400{ }^{\circ} \mathrm{C}$ the anatase-rutile transformation takes place while at $450{ }^{\circ} \mathrm{C}$ rutile is the main crystalline phase. Traces of brookite persist up to $450^{\circ} \mathrm{C}$. Brookite disappeared when the same precursor was directly treated at $450{ }^{\circ} \mathrm{C}$ for $2 \mathrm{~h}$ using a ramp rate of $2{ }^{\circ} \mathrm{C} / \mathrm{min}$ (Sample T6*). On the other hand, such thermal treatment reduces the anatase content from 30.1 (Sample T6) to 9.0\% (Sample T6*).

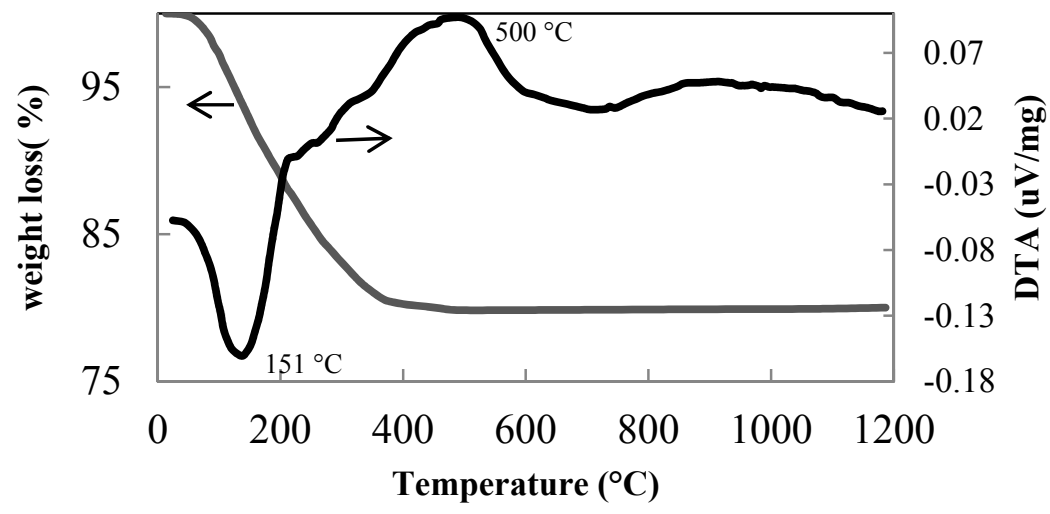

Figure 5. DTA-TGA curves of A sample reported in Table 1.

Increasing calcination temperature, the anatase crystal sizes change from $4.8 \mathrm{~nm}$ for the un-calcined precursor to $11.3 \mathrm{~nm}$ for the $450{ }^{\circ} \mathrm{C}$ calcined sample. Rutile shows significant grain growth as the anatase to rutile transition proceeds. The crystal size changes from $13.0 \mathrm{~nm}$ for the sample thermally treated at $300{ }^{\circ} \mathrm{C}$, to $24.5 \mathrm{~nm}$ after heat treatment at $450{ }^{\circ} \mathrm{C}$ (Figure 7). The detected anatase-rutile transformation indicates that the peptizing treatment with $0.1 \mathrm{M} \mathrm{HNO}_{3}$ is sufficient to promote this transformation at very low temperatures [24].

We must take into account that after the peptizing treatment with $\mathrm{HNO}_{3}$, the products were not washed with deionized water but they were directly dried in an oven at $60{ }^{\circ} \mathrm{C}$.

\subsubsection{Samples Hydrolysed with $1.0 \mathrm{M} \mathrm{NH}_{4} \mathrm{OH}$ and Peptized with $0.02 \mathrm{M} \mathrm{HNO}_{3}$}

The samples T7, T8, T9 and T10 of Table 2 form only anatase after the treatments of calcination at $450{ }^{\circ} \mathrm{C}$.

In this case the concentration of the peptizing $\mathrm{HNO}_{3}$ appears to be insufficient to promote the anatase-rutile transformation.

It must be pointed out that anatase crystals bigger in size result with a ramp rate of $30^{\circ} \mathrm{C} / \mathrm{min}^{-1}$ (T8 and T10 samples) compared with smaller crystals when a ramp rate of $2{ }^{\circ} \mathrm{C} / \mathrm{min}^{-1}$ was adopted (T7 and T9 samples).

The effect of the treatment time with the peptizing $\mathrm{HNO}_{3}$ on the anatase crystal size is not clear. An increase of the crystal sizes of anatase results with longer peptizing treatment and a calcination ramp rate of $2{ }^{\circ} \mathrm{C} / \mathrm{min}$ (T7 and $\mathrm{T} 9$ samples) while a certain reduction can be seen with a ramp rate of $30^{\circ} \mathrm{C} / \mathrm{min}$ (T8 and T10 samples) as reported in Table 2.

The increase of the crystal sizes of anatase samples involves a decreases in surface area and a corresponding increase of the average sizes of mesopores. This last feature is emphasized comparing the pore sizes distribution of T7 and T8 samples (Figure 8) determined from the BJH formula in the $\mathrm{N}_{2}$ desorption branch. 


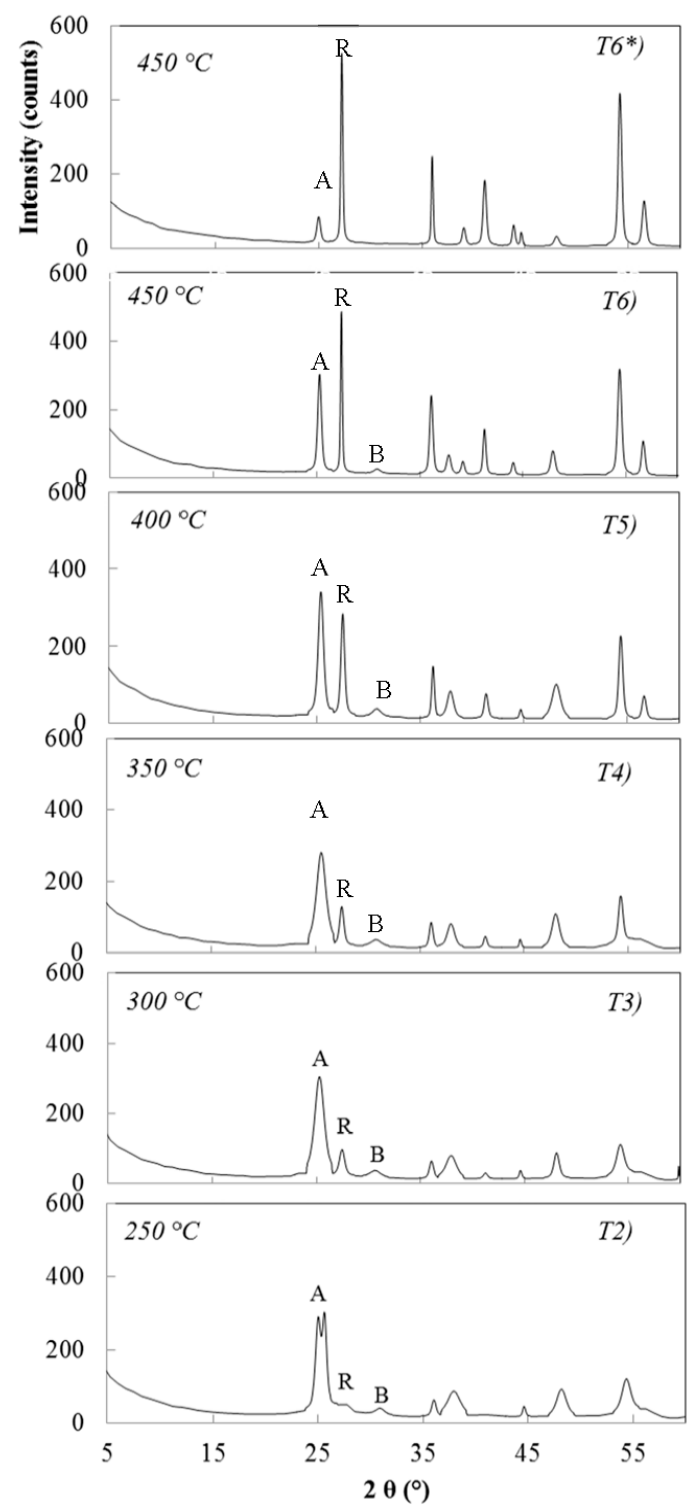

Figure 6. $\mathrm{XRD}$ patterns of samples $\mathrm{T} 2, \mathrm{~T} 3, \mathrm{~T} 4, \mathrm{~T} 5, \mathrm{~T} 6, \mathrm{~T} 6^{*}$ reported in Table 2. $(\mathrm{A}=$ anatase; $\mathrm{R}=$ rutile; $\mathrm{B}=$ brookite).

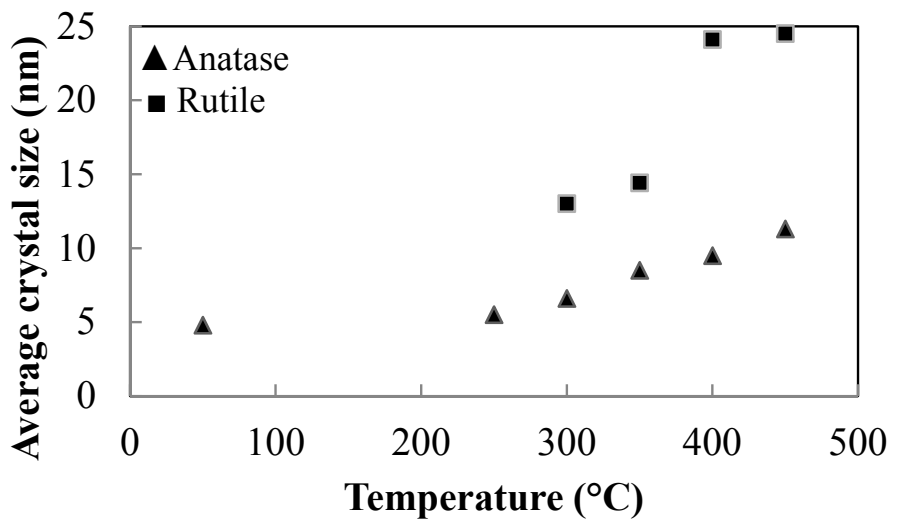

Figure 7. Average crystallite size of sample A listed in Table 1 at increasing temperature of calcination. 


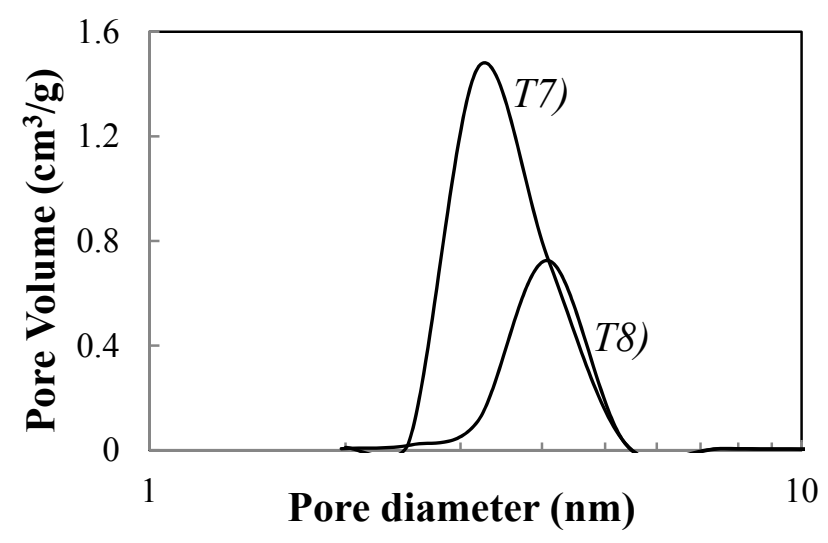

Figure 8. Pore size distribution of samples T7 and T8 determined according to BJH formula in desorption brunch of $\mathrm{N}_{2}$.

\subsubsection{Sample Hydrolyzed with $1.0 \mathrm{M} \mathrm{NH}_{4} \mathrm{OH}$ and Peptized with $0.1 \mathrm{M} \mathrm{HNO}_{3}$}

The samples T11, T12, T13, T14 and T15 listed in Table 2 have been obtained in the presence of the highest concentrations of both catalysing and peptizing agents. Also in this case, the calcination of these samples peptized with $0.1 \mathrm{M} \mathrm{HNO}_{3}$ favours the crystallization of rutile. The comparison between the XRD patterns of the sample T11, heat treated for $2 \mathrm{~h}$ at $450{ }^{\circ} \mathrm{C}$, with that of the sample T12, heat treated for $2 \mathrm{~h}$ at $600{ }^{\circ} \mathrm{C}$ (Figure 9), shows an increase of rutile content from $65 \%$ to $100 \%$.

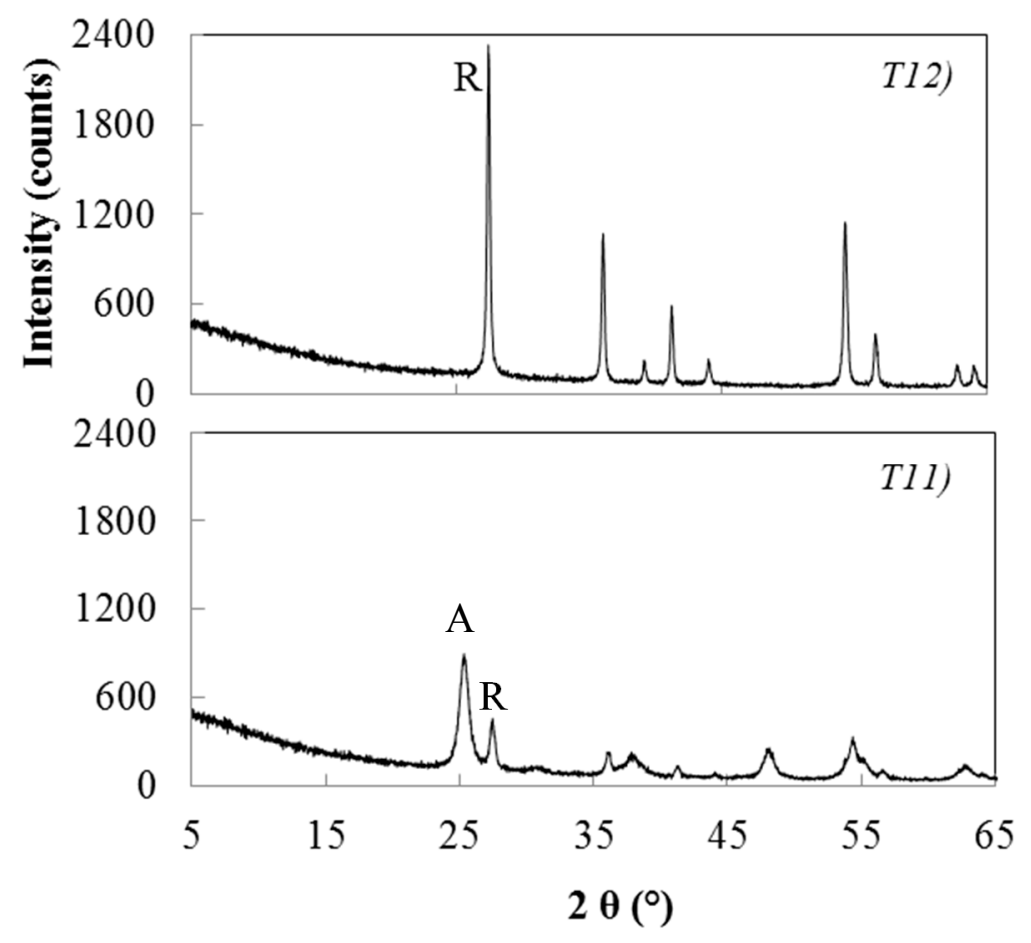

Figure 9. XRD patterns of sample $\mathrm{T} 11$ and $\mathrm{T} 12 .(\mathrm{A}=$ anatase; $\mathrm{R}=$ rutile).

The higher ramp rate adopted up to the temperature of calcination also favours the formation of rutile as results by comparing T11 and T14 samples with T13 and T15 samples (Table 2). On the contrary, the crystallization of anatase is favoured when the treatment time with the peptizing $\mathrm{HNO}_{3}$ is increased (T13 and T14 samples in Table 2). In all of the calcined samples containing mixtures of anatase and rutile, the crystallite sizes of the rutile phase are on average twice that of anatase, confirming 
that the transition of anatase to rutile is generally accompanied by significant grain growth $[27,28]$. The calcined products listed in Table 2 are characterized by average pore diameter on order of 3-5 nm.

\subsection{Hydrolysis, Peptization and Calcination of Titania in Mixture with Zirconia (5 mol \%)}

In Table 3 the crystal sizes and polymorph phases of titania are summarized for the products obtained by co-hydrolysis of $\mathrm{Ti}\left(\mathrm{OC}_{2} \mathrm{H}_{5}\right)_{4}$ in mixture with $\mathrm{Zr}\left(\mathrm{OC}_{3} \mathrm{H}_{7}\right)_{4}(5 \mathrm{~mol} \%)$.

Table 3. Anatase crystal sizes of samples obtained by hydrolysis of $\mathrm{Ti}\left(\mathrm{OC}_{2} \mathrm{H}_{5}\right)_{4}$ in mixture with $\mathrm{Zr}\left(\mathrm{OC}_{3} \mathrm{H}_{7}\right)_{4}(5 \mathrm{~mol} \%)$ catalysed for $1 \mathrm{~h}$ in the presence of $1.0 \mathrm{M} \mathrm{NH}_{4} \mathrm{OH}$ and peptized or not with different concentration of $\mathrm{HNO}_{3}$ for $1 \mathrm{~h}$ or $3 \mathrm{~h}$ followed by heat treatment for $2 \mathrm{~h}$ at $450{ }^{\circ} \mathrm{C}$ or $600{ }^{\circ} \mathrm{C}$ with a ramp rate of $2{ }^{\circ} \mathrm{C}$ or $30^{\circ} \mathrm{C} \mathrm{min}-1$, respectively.

\begin{tabular}{|c|c|c|c|c|c|}
\hline Sample & $\begin{array}{c}\qquad \mathrm{NH}_{4} \mathrm{OH} \\
\text { Concentration (M)/ } \\
\text { Treatment Time (h) }\end{array}$ & $\begin{array}{l}\qquad \mathrm{HNO}_{3} \\
\text { Concentration (M)/ } \\
\text { Treatment Time (h) }\end{array}$ & $\begin{array}{c}\text { Calcination Temperature } \\
\qquad \begin{array}{c}\left.{ }^{\circ} \mathrm{C}\right) / \text { Heating Rate } \\
\left({ }^{\circ} \mathrm{C} \text { min }^{-1}\right)\end{array}\end{array}$ & $\begin{array}{c}\text { Crystal } \\
\text { Size by } \\
\text { XRD (nm) }\end{array}$ & $\begin{array}{c}\text { Polymorphic } \\
\text { Phase A } \\
\text { (Anatase) }\end{array}$ \\
\hline $\mathrm{E}$ & $1.0 / 1$ & $0 / 0$ & $450 / 2$ & 15.7 & $\mathrm{~A}$ \\
\hline $\mathrm{F}$ & $1.0 / 1$ & $0 / 0$ & $600 / 2$ & 18.4 & $\mathrm{~A}$ \\
\hline G & $1.0 / 1$ & $0.02 / 1$ & $450 / 2$ & 11.5 & $\mathrm{~A}$ \\
\hline $\mathrm{H}$ & $1.0 / 1$ & $0.02 / 3$ & $450 / 2$ & 7.5 & $\mathrm{~A}$ \\
\hline I & $1.0 / 1$ & $0.05 / 1$ & $450 / 2$ & 7.3 & A \\
\hline $\mathrm{J}$ & $1.0 / 1$ & $0.05 / 3$ & $450 / 2$ & 6.0 & A \\
\hline $\mathrm{L}$ & $1.0 / 1$ & $0.1 / 1$ & $450 / 2$ & 6.3 & A \\
\hline M & $1.0 / 1$ & $0.1 / 1$ & $600 / 2$ & 8.5 & A \\
\hline $\mathrm{N}$ & $1.0 / 1$ & $0.1 / 1$ & $450 / 30$ & 16.0 & A \\
\hline
\end{tabular}

These products have been catalysed for $1 \mathrm{~h}$ in the presence of $1.0 \mathrm{M} \mathrm{NH}_{4} \mathrm{OH}$ and peptized or not with different concentration of $\mathrm{HNO}_{3}$ for $1 \mathrm{~h}$ or $3 \mathrm{~h}$ followed by heat treatment for $2 \mathrm{~h}$ at $450{ }^{\circ} \mathrm{C}$ or $600{ }^{\circ} \mathrm{C}$ with a ramp rate of $2^{\circ} \mathrm{C}$ or $30^{\circ} \mathrm{C} \mathrm{min}^{-1}$, respectively.

The presence of $\mathrm{Zr}$ in titania-zirconia ( $5 \mathrm{~mol} \%$ ) solid solution is confirmed by the shift at low angle of the maximum of (101) peak of anatase $((b)$ in Figure 10) compared to that of pure titania $((a)$ in Figure 10). This behaviour is due to bigger ionic radius of $\mathrm{Zr}(0.086 \mathrm{~nm})$ respect to that of $\mathrm{Ti}(0.068 \mathrm{~nm})$. In addition it is well known that $\mathrm{Zr}$ promotes a reduction of titania crystallite size [29,30] as it can be seen from larger line broadening of solid solution main peak (Figure 10). The presence of $\mathrm{Zr}$ in solid solution is also confirmed comparing in EDS analysis (Figure 11) the same samples reported in Figure 10 .

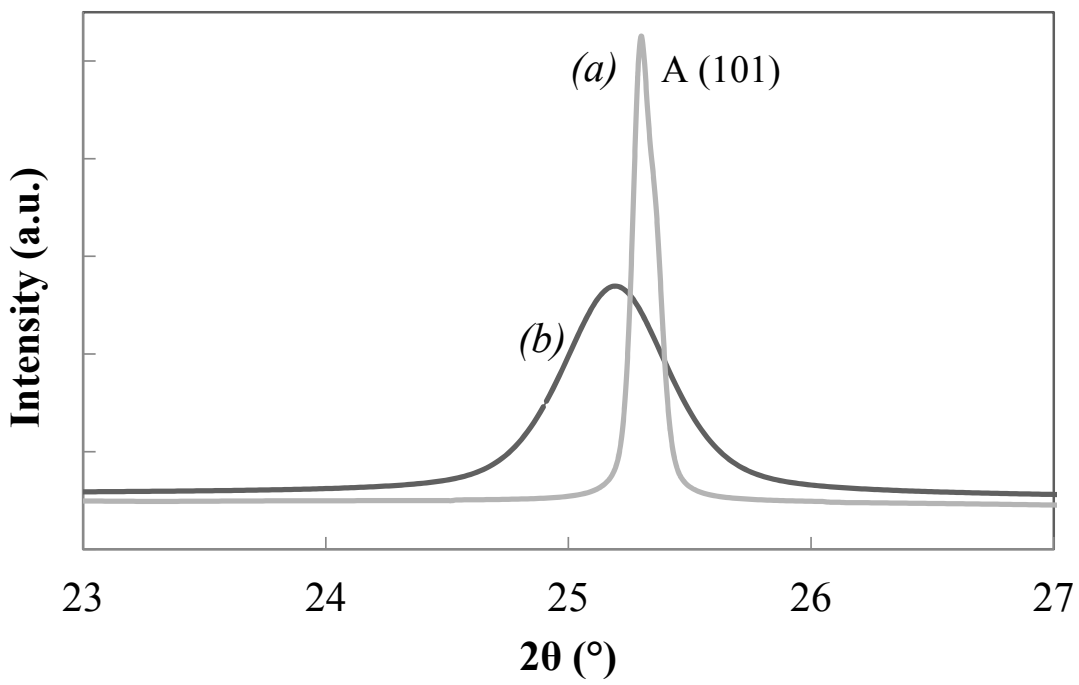

Figure 10. Anatase peak (101) of pure titania (a), T9 sample in Table 2, and of titania-zirconia (5 mol \%) solid solution (b), sample $\mathrm{H}$ in Table 3 , both calcined at $450{ }^{\circ} \mathrm{C}$. 

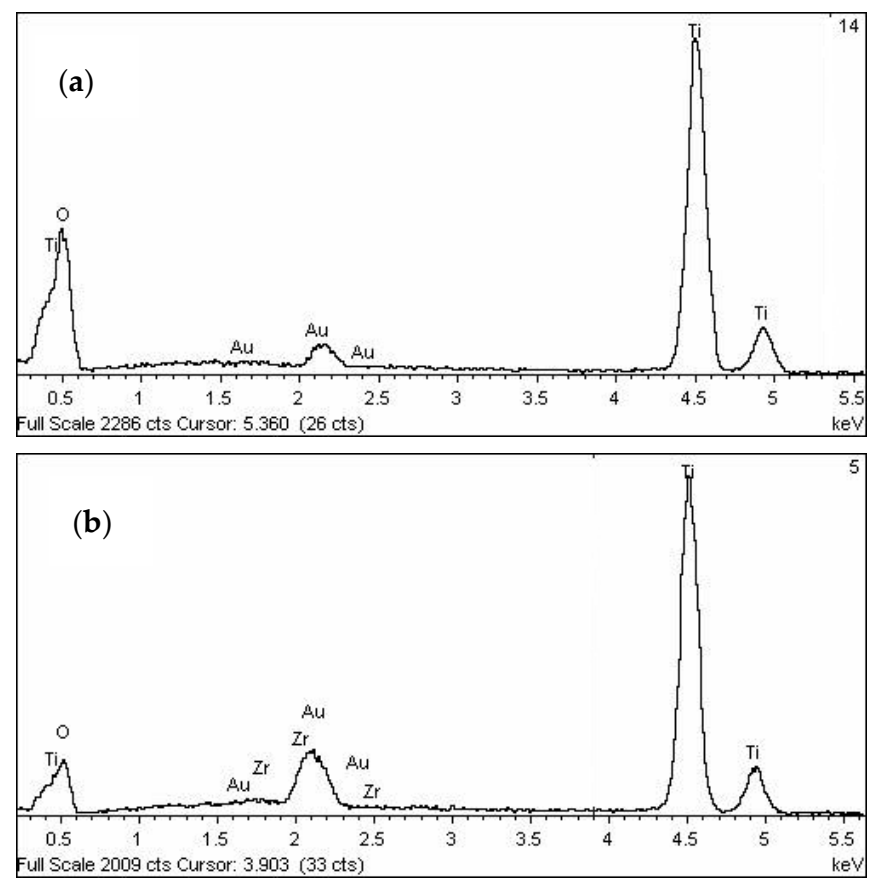

Figure 11. EDX analysis of T9 (a), and H (b), samples.

It can be seen that after calcination only anatase is present with crystal sizes that are affected by several features (Table 3):

1. The calcination of the unpeptized samples favours the crystallization of anatase with relatively larger crystals (samples E and F).

2. Upon calcination, the peptized samples form anatase with crystals that are relatively smaller in size (samples G, H, I, J, L, M).

3. The peptizing treatment with increasing concentration of $\mathrm{HNO}_{3}$ reduces the anatase crystal size for samples G, I and L, which were subjected to the same peptizing time of $1 \mathrm{~h}$ and to the same heat treatment for $2 \mathrm{~h}$ at $450{ }^{\circ} \mathrm{C}$.

4. The heat rate in calcination significantly affects the crystal size of anatase. Comparing sample $\mathrm{L}$, heated at $2{ }^{\circ} \mathrm{C} / \mathrm{min}$, with sample $\mathrm{N}$ heat treated at $30^{\circ} \mathrm{C} / \mathrm{min}$, very different crystal sizes have been detected. For sample L, the average crystal size was $6.3 \mathrm{~nm}$, while for sample $\mathrm{N}$ it was $17.0 \mathrm{~nm}$.

5. After calcination at either $450{ }^{\circ} \mathrm{C}$ or $600{ }^{\circ} \mathrm{C}$, no anatase-to-rutile phase transformation has been detected. This confirms the inhibitory effect of zirconia on the anatase-to-rutile phase transition observed in the literature [26].

6. Larger anatase crystal sizes result for products thermally treated at $600{ }^{\circ} \mathrm{C}$, compared with those treated at $450{ }^{\circ} \mathrm{C}$ (Samples E, F and L, M).

\subsection{Morphology of Un-Peptized, Peptized and Calcined Products}

SEM micrographs reported in Figure 12 show the morphology of both un-peptised sample (Figure 12a) obtained by hydrolysis catalysed for $1 \mathrm{~h}$ in the presence of $1.0 \mathrm{M} \mathrm{NH}_{4} \mathrm{OH}$ and of the corresponding product peptized for $3 \mathrm{~h}$ with $0.1 \mathrm{M} \mathrm{HNO}_{3}$ (Figure 12b), both dried in air at $60{ }^{\circ} \mathrm{C}$. The unpeptised sample show spherical and poor agglomerated particles of amorphous titania (Figure 12a). Owing the $3 \mathrm{~h}$ peptization treatment the starting spherical particles disappear and a very homogenous texture results as a consequence of the complete agglomeration among the particles (Figure 12b). The homogeneous texture corresponds to the crystallized anatase according to XRD analysis. No significant differences in the morphology between peptized and the corresponding 
calcined samples have been detected. All the products obtained after the calcination are characterized by a heterogeneous particle size distribution with average particle sizes of a few microns. Rarely, particles below $1 \mu \mathrm{m}$ in size have been observed.
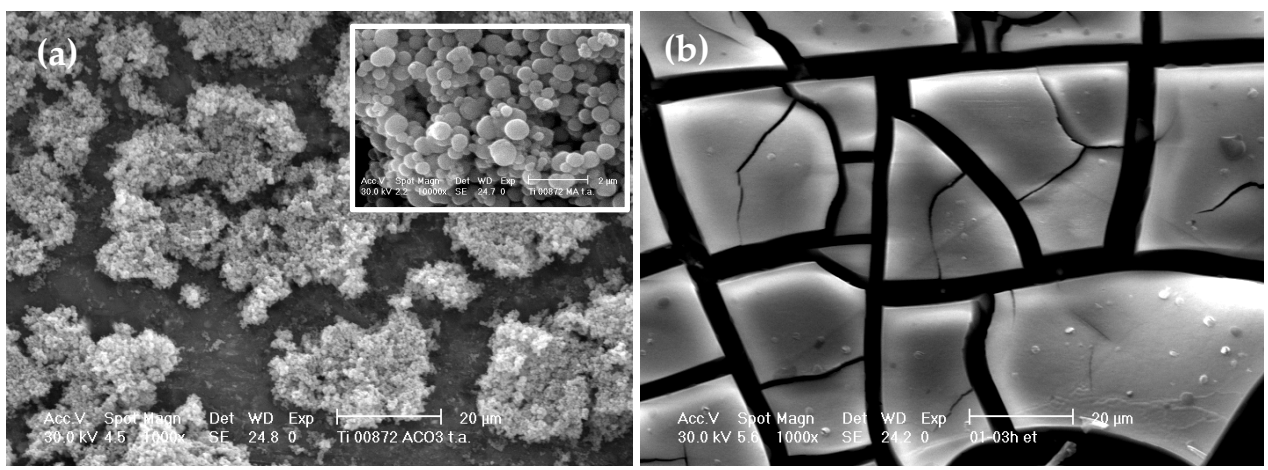

Figure 12. SEM micrographs of un-peptized sample (a) and of the same product peptized for $3 \mathrm{~h}$ with $0.1 \mathrm{M} \mathrm{HNO}_{3}(\mathbf{b})$.

\subsection{Effect of Drying Method on the Aggregation of Titania Particles}

The drying method of the peptized precursors affects the aggregation of titania particles, which in turn determines the type of porosity before and after calcination. Peptization with a dilute concentration of $\mathrm{HNO}_{3}$ results in amorphous materials (Figure 13a,c) with a BET surface area of $328.3 \mathrm{~m}^{2} / \mathrm{g}$ for the lyophilized and $287.0 \mathrm{~m}^{2} / \mathrm{g}$ for the $60{ }^{\circ} \mathrm{C}$ air-dried sample, while, after calcination, crystalline anatase is obtained with crystal sizes of $24.6 \mathrm{~nm}$ for the lyophilized sample compared to $19.8 \mathrm{~nm}$ for the heat-dried sample (Figure 13b,d). The calcination of the lyophilized sample produces a microporous structure (Figure 14), while the heat-dried and calcined sample is structurally micro-/mesoporous (Figure 15). Correspondingly, BET surface areas decrease to 52.2 and $19.3 \mathrm{~m}^{2} / \mathrm{g}$, respectively.
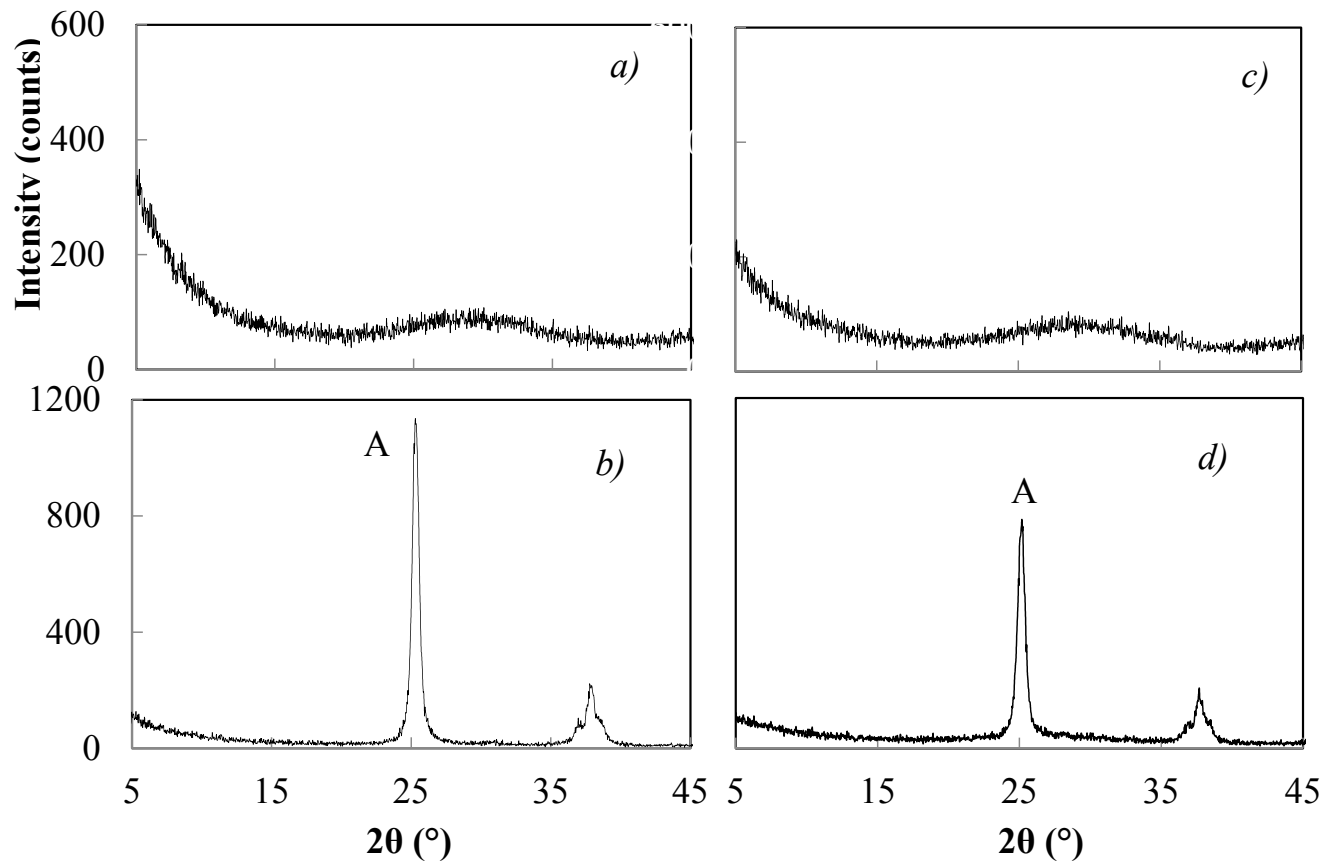

Figure 13. XRD patterns of sample hydrolysed at r.t. for $1 \mathrm{~h}$ with $1.0 \mathrm{M} \mathrm{NH}_{4} \mathrm{OH}$, peptized for $1 \mathrm{~h}$ with $0.02 \mathrm{M} \mathrm{HNO}_{3}$, dried by lyophilization $(\mathbf{a}, \mathbf{b})$ or at $60{ }^{\circ} \mathrm{C}(\mathbf{c}, \mathbf{d})$ and calcined for $2 \mathrm{~h}$ at $450{ }^{\circ} \mathrm{C}$ with a ramp rate of $30^{\circ} \mathrm{C} / \mathrm{min}(\mathbf{b}, \mathbf{d})$. $(\mathrm{A}=$ anatase $)$. 


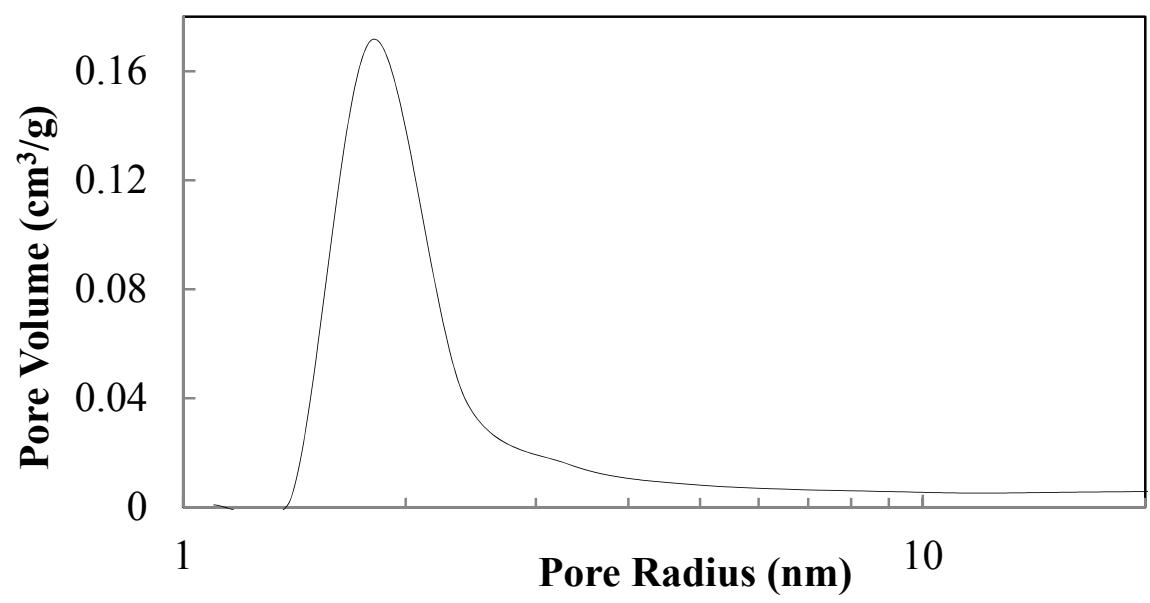

Figure 14. Pore size distribution of sample hydrolysed at r.t. for $1 \mathrm{~h}$ with $1.0 \mathrm{M} \mathrm{NH}_{4} \mathrm{OH}$, peptized for $1 \mathrm{~h}$ with $0.02 \mathrm{M} \mathrm{HNO}_{3}$, dried by lyophilization and calcined for $2 \mathrm{~h}$ at $450{ }^{\circ} \mathrm{C}$ with a ramp rate of $30{ }^{\circ} \mathrm{C} / \mathrm{min}$.

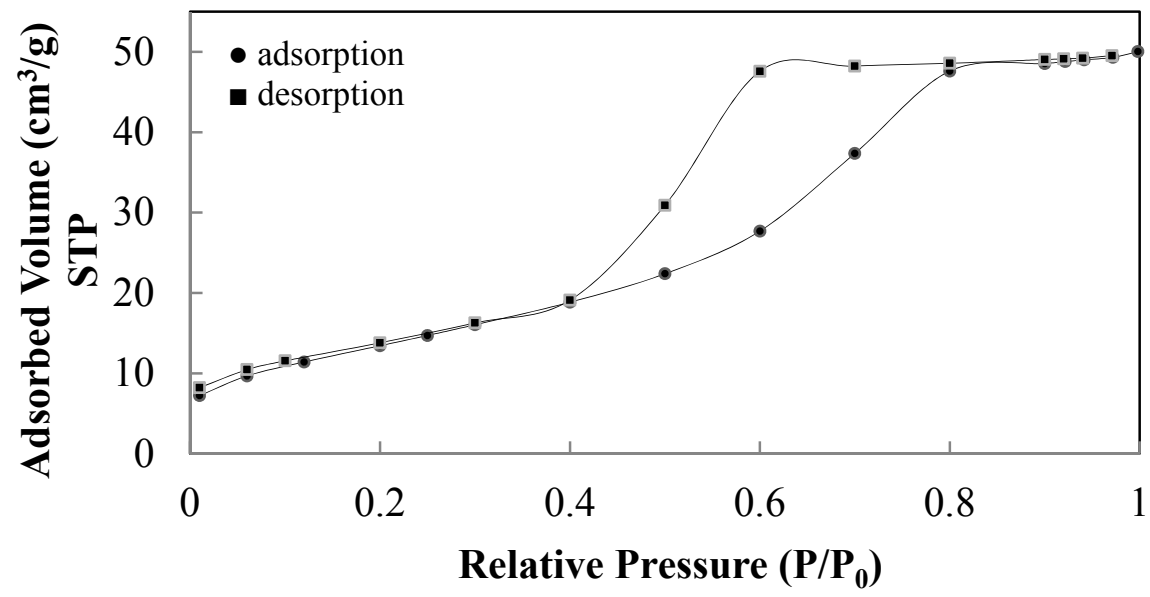

Figure 15. $\mathrm{N}_{2}$ adsorption-desorption curves of sample hydrolysed at r.t. for $1 \mathrm{~h}$ with $1.0 \mathrm{M} \mathrm{NH}_{4} \mathrm{OH}$, peptized for $1 \mathrm{~h}$ with $0.02 \mathrm{M} \mathrm{HNO}_{3}$, dried at $60{ }^{\circ} \mathrm{C}$ and calcined for $2 \mathrm{~h}$ at $450{ }^{\circ} \mathrm{C}$ with a ramp rate of $30{ }^{\circ} \mathrm{C} / \mathrm{min}$.

As previously mentioned, anatase-rutile mixtures result when the calcination is performed on precursors peptized with $1.0 \mathrm{M} \mathrm{HNO}_{3}$. The peptized precursors, dried by lyophilization or at $60^{\circ} \mathrm{C}$, contain nanometer anatase with a crystallite size of 4.5 and $5.2 \mathrm{~nm}$, respectively (Figure 16a,b). After calcination, the lyophilized sample is characterized by bigger crystallite sizes and, consequently, by a smaller anatase-rutile molar ratio compared to the heat-dried sample.

Morphological differences between lyophilized and heat treated samples have been observed after calcination. The lyophilized sample (Figure 17a) shows a minor aggregation among titania particles compared with the same precursor dried by heat treatment (Figure 17b). Consequently, interparticle macropores of titania can be detected for the lyophilized sample while the sample dried by heat treatment manifests micrometric titania aggregates characterized by intraparticle mesopores. 

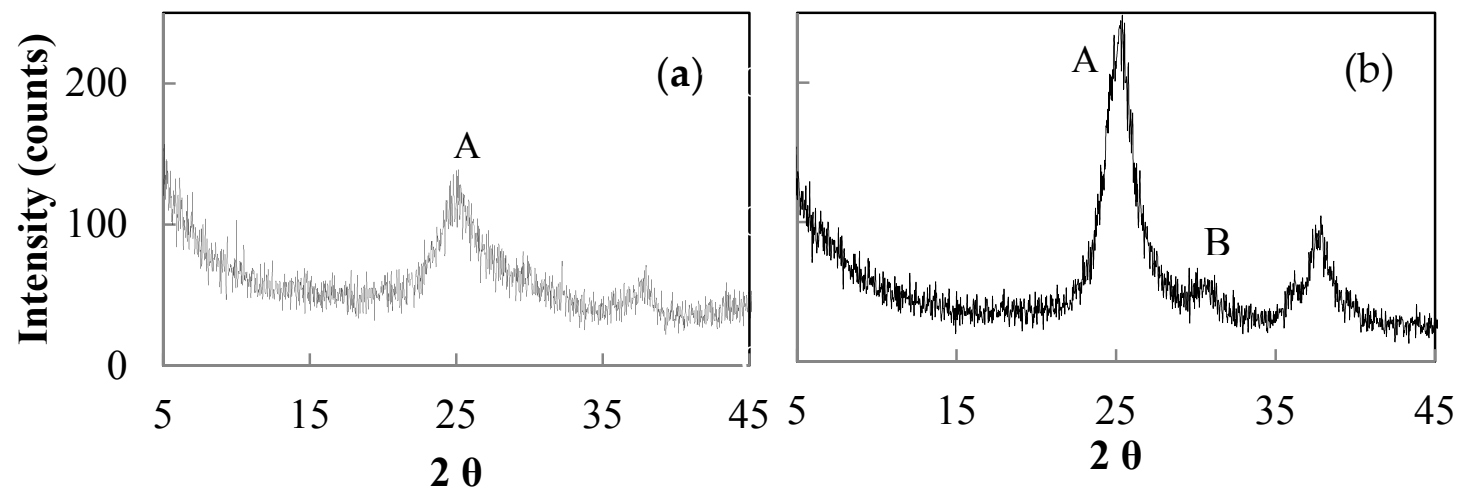

Figure 16. XRD patterns of sample hydrolysed at r.t. for $1 \mathrm{~h}$ with $1.0 \mathrm{M} \mathrm{NH}_{4} \mathrm{OH}$, peptized for $1 \mathrm{~h}$ with $0.1 \mathrm{M} \mathrm{HNO}_{3}$, dried by lyophilization (a) or at $60{ }^{\circ} \mathrm{C} \mathrm{(b)} \mathrm{and} \mathrm{calcined} \mathrm{for} 2 \mathrm{~h}$ at $450{ }^{\circ} \mathrm{C}$ with a ramp rate of $30^{\circ} \mathrm{C} / \mathrm{min}(\mathbf{b}, \mathbf{d})$. $(\mathrm{A}=$ anatase; $\mathrm{B}=$ brookite $)$.
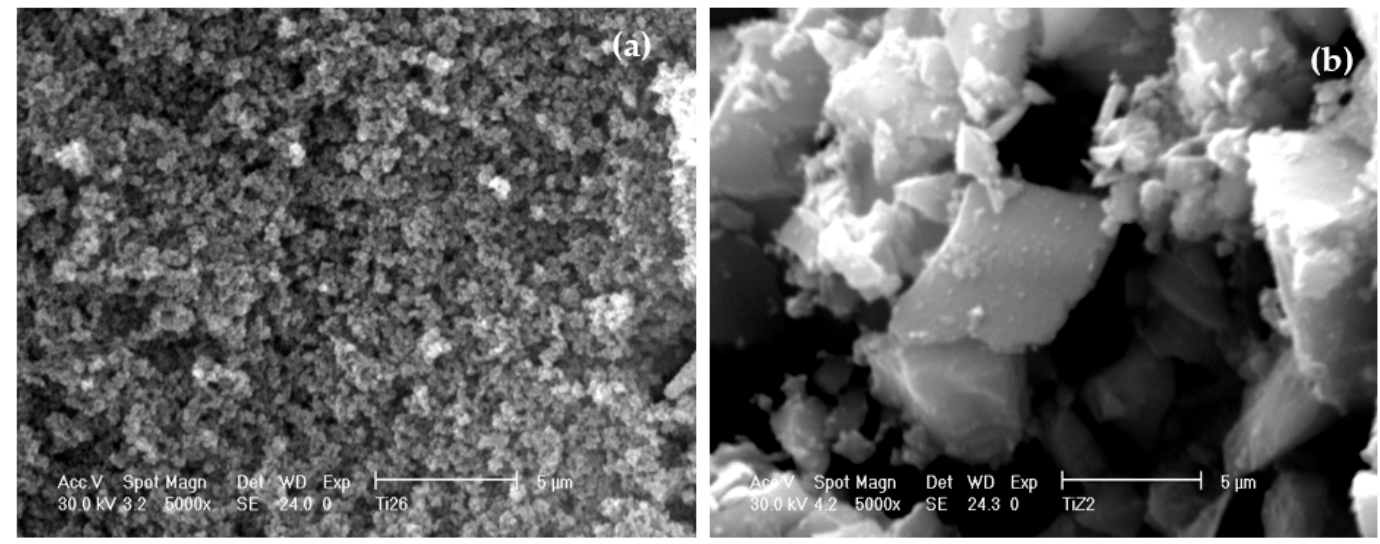

Figure 17. SEM micrographs of the sample hydrolysed at r.t. for $1 \mathrm{~h}$ with $0.07 \mathrm{M} \mathrm{NH}_{4} \mathrm{OH}$, peptized for 1h with $0.05 \mathrm{M} \mathrm{HNO}_{3}$, dried by lyophilization (a) or at $60{ }^{\circ} \mathrm{C}(\mathbf{b})$ and calcined for $2 \mathrm{~h}$ at $450{ }^{\circ} \mathrm{C}$.

\section{Discussion}

It is well known that rutile polymorph is the stable phase of titania at room temperature, while anatase and brookite are thermodynamically metastable [21]. The existence of anatase at room temperature is due to the fact that it is kinetically stabilized at room temperature [26]. The transformation upon calcination of amorphous titania to crystalline anatase takes place in the temperature range between $350^{\circ} \mathrm{C}$ and $450{ }^{\circ} \mathrm{C}$, while the anatase-rutile transformation occurs between $600{ }^{\circ} \mathrm{C}$ and $1100{ }^{\circ} \mathrm{C}$ [31]. This last transformation is affected by oxygen defect levels [32], which in turn depend on the impurities, inhibitors or promoters of the anatase-to-rutile phase transition. Nitrogen as a $\mathrm{TiO}_{2}$ dopant is a typical promoter of the anatase-to-rutile phase transformation [33,34]. The peptizing treatment of un-doped titania xerogels of with $0.1 \mathrm{M} \mathrm{HNO}_{3}$ at $\mathrm{pH}=1$ favours the crystallization of anatase with crystallites very small in size on the order of $4.6 \mathrm{~nm}$, while amorphous products results when the same treatment is performed with diluted solution of $\mathrm{HNO}_{3}$, corresponding to $\mathrm{pH}=6.5$. The calcination of pure titania xerogel or of the corresponding peptized samples with diluted solution of $\mathrm{HNO}_{3}$ promotes the crystallization of anatase with crystals larger in size than those corresponding xerogel peptized in the presence of $0.1 \mathrm{M} \mathrm{HNO}_{3}$. This result can be justified in terms of different reactivity. The higher reactivity on calcination of amorphous precursors justifies the formation of anatase with crystals larger in size compared to those of crystalline precursors resulting after peptization with $0.1 \mathrm{M} \mathrm{HNO}_{3}$. It is well known that a higher initial primary particle size reduces the grain growth rate of crystals with increasing temperature [31]. The precursors peptized in the presence of diluted $\mathrm{HNO}_{3}$ do not show the anatase-rutile transformation after calcination either 
when the precursors have been peptized for different times ( 1 or $3 \mathrm{~h}$ ) or when ramp rates of $2{ }^{\circ} \mathrm{C}$ or $30{ }^{\circ} \mathrm{C} /$ min were adopted. In these circumstances shorter times of peptization with diluted $\mathrm{HNO}_{3}$ favour the formation of anatase crystals larger in size compared with the smaller ones detected for longer treatment times. In the last case the dissolution of more reactive particles of the xerogel is favoured, with consequential reduction of the crystal growth of anatase. The high calcination ramp rate also enhances the formation of large anatase crystals due to a possible nucleation and crystal growth mechanism during the anatase crystallization. A high ramp rate involves a shorter time in the temperature range of nucleation, thus reducing the concentration of the nuclei with consequent formation of crystals of larger size. This behaviour contrasts with the results obtained on calcination of amorphous precursors showing a reduction of the titania crystal size when a high heating rate was adopted [35].

The calcination of the precursors obtained from titania xerogel peptized in the presence of $0.1 \mathrm{M} \mathrm{HNO}_{3}$ gives rise to the anatase-to-rutile transformation. According to [36,37], the temperature of the anatase-to-rutile phase transformation decreases with a smaller crystal size of the anatase precursor. Such behaviour is confirmed by the lowest temperature transition $\left(250{ }^{\circ} \mathrm{C}\right)$ detected for precursors with crystal size of anatase of order of $4.6 \mathrm{~nm}$ obtained by peptization of titania xerogel in the presence of $0.1 \mathrm{M} \mathrm{HNO}_{3}$. The tendency to form rutile is also enhanced by high temperature of calcination, high ramp rate up to the calcination temperature and finally low treatment time of peptization. Such parameters allow us to obtain mixtures of anatase-rutile in different amounts and with variable crystallite sizes. The peptizing treatments of titania xerogels containing 5 mol \% zirconia in the presence of increasing concentration of $\mathrm{HNO}_{3}$ determine, in a similar way to pure titania xerogel, precursors characterized on calcination by a high crystallinity but with anatase crystals decreasing in size. Both unpeptized and peptized samples, both thermally treated at $600{ }^{\circ} \mathrm{C}$, do not form rutile confirming the inhibitor role of zirconia in the anatase-rutile transformation [26]. In this circumstance, the inhibitor effect of zirconia prevails over the promoter effect of nitrogen doping.

The aggregation of titania particles that takes place either under stirring during the hydrolysis or the drying method of the corresponding precursors affects both the crystal and pore size of crystallized phases upon calcination. The formation of the mesoporous structure of titania appears to be significantly related to the drying method; in particular no significant mesopores result when drying is performed by lyophilization or in air at room temperature. On the contrary, the drying by heat treatment at $60^{\circ} \mathrm{C}$ appears to favour a mesoporous structure. The mesoporous products are in the micrometers in size and show an easy tendency toward sedimentation when dispersed in aqueous suspensions [7]. Such a feature is very useful in catalysis production because an easy, recyclable process can be performed. A few minutes are sufficient for the quiescent sedimentation of the calcined products with a slight opalescent supernatant persisting for a few hours. In comparison, the commercial product P25 (Degussa) requires longer sedimentation with a milky opalescence that persists for several hours.

\section{Conclusions}

Micrometer aggregates of mesoporous titania based on anatase or anatase-rutile mixtures have been prepared from $\mathrm{TiO}_{2}$ precursors peptized with $0.1 \mathrm{M} \mathrm{HNO}_{3}(\mathrm{pH}=1)$ at $50{ }^{\circ} \mathrm{C}$ and subsequently calcined. Nitrogen in $\mathrm{HNO}_{3}$ has proved to be an effective promoter of anatase-rutile transformation. However, adequate $\mathrm{HNO}_{3}$ concentrations and peptizing times are required. In the presence of $0.1 \mathrm{M} \mathrm{HNO}_{3}$ the peptization time should not be less than $1 / 2 \mathrm{~h}$ and not more than $3 \mathrm{~h}$. In the first case, the promoter effect of the anatase-rutile transformation is reduced, while in the latter the dissolution of the gel takes place especially when more concentrated $\mathrm{HNO}_{3}$ solutions are used.

The peptization promotes the formation of crystalline anatase with a very small crystal size on the order of 4.6-4.8 nm. The calcination of such peptized precursors determines the anatase-rutile transformation with a percentage ratio that can be changed with the crystal size of crystallized titania. The rutile formation is favoured by larger crystals, obtained by changing various parameters of 
synthesis, to control the crystal size of titania and the amount of crystalline rutile. When the precursor is peptized with diluted $\mathrm{HNO}_{3}$ solution, the rutile crystallizes only at high temperature, with a drastic reduction in both the surface area and catalytic activity. The rutile content from precursors peptized with $0.1 \mathrm{M} \mathrm{HNO}_{3}$ increases according to the following parameters: high concentration of catalysing $\mathrm{NH}_{4} \mathrm{OH}$, low peptizing time, high temperature of calcination and high ramp rate up to calcination temperature.

After calcination the $\mathrm{TiO}_{2}$ in mixture with $5 \mathrm{~mol} \% \mathrm{ZrO}_{2}$ up to $600{ }^{\circ} \mathrm{C}$, only anatase is produced either for un-peptized or peptized precursors showing a prevalent inhibitor effect of zirconia on the anatase to rutile transition compared to the promoter effect of $\mathrm{HNO}_{3}$. Smaller anatase crystal sizes result for peptized precursors compared with un-peptized ones. High values of both the calcination temperature and the ramp rate favour large anatase crystal sizes.

The drying method of precursors before calcinations significantly affects the porous structure of both dried and calcined products. The agglomeration of titania particles takes place not only during the hydrolyzing step and peptizing treatment but it is also altered by the drying method. In particular, drying in air at room temperature and lyophilization appear unfavourable for the formation of mesoporous structure. Heat drying treatments form mesoporous structures. Before and after the calcination treatment all the products are characterized by a heterogeneous distribution of particles sizes of order of several micrometers. These particles are easily separated by sedimentation. Such a feature is very useful in catalysis preparation because an easy, recyclable process can be performed.

From these results, we can conclude that the objectives to obtain recyclable aggregates of mesoporous titania as anatase form or as anatase-rutile mixtures with different ratio and characterized by variable values of both crystallinity and surface area have been attained. The next objective is to select from these products those with appropriate characteristics to be tested as recyclable photocatalysts.

Author Contributions: M.C.M. conceived and designed the experiments; M.C.M. performed the experiments; M.C.M. and T.A.R. analyzed the data; M.C.M. contributed reagents/materials/analysis tools; M.C.M. and T.A.R. wrote the paper.

Conflicts of Interest: The authors declare no conflict of interest.

\section{References}

1. Kresge, C.T.; Leonowicz, M.E.; Roth, W.J.; Vartuli, J.C.; Beck, J.S. Ordered mesoporous molecular sieves synthesized by a liquid-crystal template mechanism. Nature 1992, 359, 710-712. [CrossRef]

2. Chen, X.; Mao, S.S. Titanium Dioxide Nanomaterials: Synthesis, Properties, Modifications, and Applications. Chem. Rev. 2007, 107, 2891-2959. [CrossRef] [PubMed]

3. Nah, Y.C.; Paramasivam, I.; Schmuki, P. Doped $\mathrm{TiO}_{2}$ and $\mathrm{TiO}_{2}$ nanotubes: Synthesis and applications. Chem. Phys. Chem. 2010, 11, 2698-2713. [CrossRef] [PubMed]

4. Davis, S.A.; Burkett, S.L.; Mendelson, N.H.; Mann, S. Bacterial templating of ordered macrostructures in silica and silica-surfactant mesophases. Nature 1997, 385, 420-423. [CrossRef]

5. Chae, W.S.; Land, S.W.; Kim, Y.R. Templating route to mesoporous nanocrystalline titania nanofibers. Chem. Mater. 2005, 17, 3072-3074. [CrossRef]

6. Ismail, A.A.; Bahnemann, D.W. Mesoporous titania photocatalysts: Preparation, characterization and reaction mechanisms. J. Mater. Chem. 2011, 21, 11686-11707. [CrossRef]

7. Tammaro, M.; Fiandra, V.; Mascolo, M.C.; Salluzzo, A.; Riccio, C.; Lancia, A. Photocatalytic degradation of atenolol in aqueous suspension of new recyclable catalysts based on titanium dioxide. J. Environ. Chem. Eng. 2017, 5, 3224-3234. [CrossRef]

8. Lu, P.J.; Huang, S.C.; Chen, Y.P.; Chiueh, L.; ChihShih, D. Analysis of titanium dioxide and zinc oxide nanoparticles in cosmetics. J. Food Drug Anal. 2015, 23, 587-594. [CrossRef] [PubMed]

9. Atabaev, T.S.; Hossain, M.A.; Lee, D.; Kim, H.K.; Hwang, Y.H. Pt-coated $\mathrm{TiO}_{2}$ nanorods for photoelectrochemical water splitting applications. Results Phys. 2016, 6, 373-376. [CrossRef] 
10. Ji, Y.; Zhou, L.; Ferronato, C.; Yang, X.; Salvador, A.; Zeng, C.; Chovelon, J. Photocatalytic degradation of atenolol in aqueous titanium dioxide suspensions: Kinetics, intermediates and degradation pathways. J. Photochem. Photobiol. A Chem. 2016, 254, 35-44. [CrossRef]

11. Chemseddine, A.; Moritz, T. Nanostructuring Titania: Control over Nanocrystal Structure, Size, Shape, and Organization. Eur. J. Inorg. Chem. 1999, 1999, 235-245. [CrossRef]

12. Buonsanti, R.; Grillo, V.; Carlino, E.; Giannini, C.; Kipp, T.; Cingolani, R.; Cozzoli, P.D. Nonhydrolytic Synthesis of High-Quality Anisotropically Shaped Brookite $\mathrm{TiO}_{2}$ Nanocrystals. J. Am. Chem. Soc. 2008, 130, 11223-11233. [CrossRef] [PubMed]

13. Likodimos, V.; Chrysi, A.; Calamiotou, M.; Fernández-Rodríguez, C.; Doña-Rodríguez, J.M.; Dionysiou, D.D.; Falaras, P. Microstructure and charge trapping assessment in highly reactive mixed phase $\mathrm{TiO}_{2}$ photocatalysts. Appl. Catal. B Environ. 2016, 192, 242-252. [CrossRef]

14. Puddu, V.; Choi, H.; Dionysiou, D.D.; Puma, G.L. $\mathrm{TiO}_{2}$ photocatalyst for indoor air remediation: Influence of crystallinity, crystal phase, and UV radiation intensity on trichloroethylene degradation. Appl. Catal. B Environ. 2010, 94, 211-218. [CrossRef]

15. Cargnello, M.; Gordon, T.R.; Murray, C.B. Solution-Phase Synthesis of Titanium Dioxide Nanoparticles and Nanocrystals. Chem. Rev. 2014, 114, 9319-9345. [CrossRef] [PubMed]

16. Linsebigler, A.L.; Guangquan, L.; Yates, J.T. Photocatalysis on $\mathrm{TiO}_{2}$ Surfaces: Principles, Mechanisms, and selected results. Chem. Rev. 1995, 95, 735-758. [CrossRef]

17. Byrne, J.A.; Eggins, B.R.; Brown, N.M.D.; McKinney, B.; Rouse, M. Immobilisation of $\mathrm{TiO}_{2}$ powder for the treatment of polluted water. Appl. Catal. B Environ. 1998, 17, 25-36. [CrossRef]

18. Ding, Z.; Hu, X.; Lu, G.Q.; Yue, P.; Greenfield, P.F. Novel Silica Gel Supported $\mathrm{TiO}_{2}$ Photocatalyst Synthesized by CVD Method. Langmuir 2000, 16, 6216-6222. [CrossRef]

19. Mascolo, M.C.; Pe, Y.I.; Ring, T.A. Room Temperature Co-Precipitation Synthesis of Magnetite Nanoparticles in a Large pH Window with Different Bases. Materials 2013, 6, 5549-5567. [CrossRef] [PubMed]

20. Mascolo, M.C.; Dell'Agli, G.; Mascolo, G. Mesoporous aggregates of $\mathrm{ZrO}_{2}$-doped (5 mol \%) titania by interconn ection of primary nano-particles. Microporous Mesoporous Mater. 2010, 132, 196-200. [CrossRef]

21. Mascolo, M.C. Synthesis of wide spectrum of mesoporous titania materials by forced co-hydrolysis of $\mathrm{Zr}-\mathrm{Ti}$ alkoxides. Microporous Mesoporous Mater. 2013, 181, 160-165. [CrossRef]

22. Li, G.; Yu, J.C.; Zhu, J.; Cao, Y. Hierarchical mesoporous grape-like titania with superior recyclability and photoactivity. Microporous Mesoporous Mater. 2007, 106, 278-283. [CrossRef]

23. Pelaez, M.; Nolan, N.T.; Pillai, S.C.; Seery, M.K.; Falaras, P.; Kontos, A.G.; Dunlop, P.S.; Hamilton, J.W.; Byrne, J.A.; O'shea, K.; et al. A Review on the Visible Light Active Titanium Dioxide Photocatalysts for Environmental Applications. Appl. Catal. B Environ. 2012, 125, 331-349. [CrossRef]

24. Thompson, T.L.; Yates, J.T., Jr. Surface Science Studies of the Photoactivation of $\mathrm{TiO}_{2}-\mathrm{New}$ Photochemical Processes. Chem. Rev. 2006, 106, 4428-4453. [CrossRef] [PubMed]

25. Colón, G.; Sánchez-España, J.M.; Hidalgo, M.C.; Navío, J.A. Effect of $\mathrm{TiO}_{2}$ acidic pre-treatment on the photocatalytic properties for phenol degradation. J. Photochem. Photobiol. A Chem. 2006, 179, 220-227. [CrossRef]

26. Hanaor, D.A.H.; Sorrell, C.C. Review of the anatase to rutile phase transformation. J. Mater. Sci. 2011, 46, 855-874. [CrossRef]

27. Iida, Y.; Ozaki, S. Grain Growth and Phase Transformation of Titanium Oxide During Calcination. J. Am. Ceram Soc. 1961, 44, 120-128. [CrossRef]

28. Zhang, Y.H.; Reller, A. Phase transformation and grain growth of doped nanosized titania. Mater. Sci. Eng. C 2002, 19, 323-326. [CrossRef]

29. Reddy, B.M.; Khan, A. Recent advances on $\mathrm{TiO}_{2}-\mathrm{ZrO}_{2}$ mixed oxides as catalysts and catalyst supports. Catal. Rev. Sci. Eng. 2005, 47, 257-296. [CrossRef]

30. Neppolian, B.; Wang, Q.; Yamashita, H.; Choi, H. Synthesis and characterization of $\mathrm{ZrO}_{2}-\mathrm{TiO}_{2}$ binary oxide semiconductor nanoparticles: Application and interparticle electron transfer process. Appl. Catal. A 2007, 333, 264-271. [CrossRef]

31. Ovenstone, J.; Yanagisawa, K. Effect of Hydrothermal Treatment of Amorphous Titania on the Phase Change from Anatase to Rutile during Calcination. Chem. Mater. 1999, 11, 2770-2774. [CrossRef] 
32. Li, H.; Hao, Y.; Lu, H.; Liang, L.; Wang, Y.; Qiu, J.; Shi, X.; Wang, Y.; Yao, J. A systematic study on visible-light $\mathrm{N}$-doped $\mathrm{TiO}_{2}$ photocatalyst obtained from ethylenediamine by sol-gel method. Appl. Surf. Sci. 2015, 344, 112-118. [CrossRef]

33. Peng, F.; Cai, L.; Yu, H.; Wang, H.; Yang, J. Synthesis and characterization of substitutional and interstitial nitrogen-doped titanium dioxides with visible light photocatalytic activity. J. Solid State Chem. 2008, 181, 130-136. [CrossRef]

34. Banerjee, S.; Pillai, S.C.; Falaras, P.; O'shea, K.E.; Byrne, J.A.; Dionysiou, D.D. New Insights into the Mechanism of Visible Light Photocatalysis. J. Phys. Chem. Lett. 2014, 5, 2543-2554. [CrossRef] [PubMed]

35. You, X.; Chen, F.; Zhang, J. Effects of Calcination on the Physical and Photocatalytic Properties of $\mathrm{TiO}_{2}$ Powders Prepared by Sol-Gel Template Method. J. Sol-Gel Sci. Technol. 2005, 34, 181-187. [CrossRef]

36. Gribb, A.A.; Banfiel, J.F. Particle size effects on transformation kinetics and phase stability in nanocrystalline $\mathrm{TiO}_{2}$. Am. Mineral. 1997, 82, 717-728. [CrossRef]

37. Hu, Y.; Tsai, H.L.; Huang, C.L. Effect of brookite phase on the anatase-rutile transition in titania nanoparticles. J. Eur. Ceram. Soc. 2003, 23, 691-696. [CrossRef]

(c) 2018 by the authors. Licensee MDPI, Basel, Switzerland. This article is an open access article distributed under the terms and conditions of the Creative Commons Attribution (CC BY) license (http://creativecommons.org/licenses/by/4.0/). 